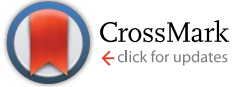

Cite this: RSC Adv., 2016, 6, 86220

Received 12th August 2016

DOI: $10.1039 / c 6 r a 20375 b$

www.rsc.org/advances
Accepted 4th September 2016

\section{Cyanoacrylic- and (1-cyanovinyl)phosphonic acid anchoring ligands for application in copper-based dye-sensitized solar cells $\dagger$}

\author{
Yann Baumgartner, Y. Maximilian Klein, Edwin C. Constable, Catherine E. Housecroft* \\ and Markus Willgert
}

The syntheses and characterization of four new anchoring ligands (2-5) for copper(1) bis(diimine) dyes in dye-sensitized solar cells (DSCS) are reported. Ligands 2 and 3 contain a 6,6'-dimethyl-2,2'-bipyridine copper-binding unit, while 4 and 5 contain a 2,9-dimethyl-1,10-phenanthroline unit; 2 and 4 contain cyanoacrylic acid anchoring units, and 3 and 5 possess (1-cyanovinyl)phosphonic acid anchors. The performance of DSCs sensitized by $\left[\mathrm{Cu}\left(\mathrm{L}_{\text {anchor }}\right)\left(\mathrm{L}_{\text {ancillary }}\right)\right]^{+}$in which $\mathrm{L}_{\text {anchor }}$ is $2-5$ and $\mathrm{L}_{\text {ancillary }}$ is either $6,6^{\prime}$-dimethyl-2,2'-bipyridine (6) or 6-trifluoromethyl-2,2'-bipyridine (7) are compared with those of DSCs containing the dyes $[\mathrm{Cu}(1)(6)]^{+}$or $[\mathrm{Cu}(1)(7)]^{+}$where anchoring ligand 1 is the previously reported and well-performing ((6,6'-dimethyl-[2,2'-bipyridine]-4,4'-diyl)bis(4,1-phenylene))bis(phosphonic acid). Among dyes incorporating $2-5$, the best performing dye contained anchor 3 (6,6'-Me $\mathrm{bpy} /(1$-cyanovinyl) phosphonic acid combination). The better performances of dyes containing the bpy-based 2 and 3 compared to the phen-based 4 and 5 are rationalized largely in terms of the greater flexibility of the bpy vs. phen unit, allowing dyes containing 2 and 3 to adopt a conformation that leads to better surface coverage on mesoporous $\mathrm{TiO}_{2}$. Replacing 1 by 3 leads to a small gain in the short-circuit current density $\left(J_{S C}\right)$, but dyes with anchor 1 (in place of 3 ) have enhanced open-circuit voltage $\left(V_{O C}\right)$. The results of electrochemical impedance spectroscopy (EIS) support the trends found from the $J-V$ measurements. The EIS data for DSCs with dyes containing anchors 3 or 1 are compared; the latter has a higher recombination resistance and chemical capacitance although the former exhibits a lower transport resistance.

\section{Introduction}

Solar-to-electrical energy conversion by Grätzel dye-sensitized solar cells (DSCs) conventionally uses ruthenium(II) photosensitizers with carboxylic acid or carboxylate groups for attachment to a mesoporous n-type semiconductor (usually $\mathrm{TiO}_{2}$ ). ${ }^{\mathbf{1 , 2}}$ State-of-the art ruthenium-based, organic and zinc(II) porphyrin-based dyes typically use carboxylic acid and cyanoacrylic acid anchors, although the palette of anchoring groups has increased significantly in recent years. ${ }^{3-7}$ The combined electron-withdrawing properties of the cyano and carboxylic acid groups in cyanoacrylic acid-anchored dyes are an integral part of the classical 'push-pull' dye design.

We have initiated a systematic assessment of copper-based sensitizers in DSCs, and have exploited the use of heteroleptic

Department of Chemistry, University of Basel, Spitalstrasse 51, CH-4056 Basel, Switzerland.E-mail: catherine.housecroft@unibas.ch

$\dagger$ Electronic supplementary information (ESI) available: Scheme S1: atom labelling for NMR; Fig. S1-S3: IR and NMR spectra; Fig. S4: solid-state absorption spectra; Fig. S5-S10: additional $J-V$ and EQE spectra. See DOI: 10.1039/c6ra20375b dyes containing a $\left[\mathrm{Cu}\left(\mathrm{N}^{\wedge} \mathrm{N}\right)\left(\mathrm{N}^{\wedge} \mathrm{N}^{\prime}\right)\right]^{+}$core $\left(\mathrm{N}^{\wedge} \mathrm{N}\right.$ and $\mathrm{N}^{\wedge} \mathrm{N}^{\prime}=2,2^{\prime}$ bipyridine or 1,10-phenanthroline-based ligands) to enable optimal combinations of anchoring and ancillary domains. We have focused on a 'surfaces-as-ligands' approach to assemble dyes in a stepwise manner on the semiconductor surface, ${ }^{\mathbf{8}, 9}$ in contrast to the HETPHEN strategy favoured by Odobel and coworkers. ${ }^{10}$ While the photoconversion efficiencies, $\eta$, of copper-based DSCs are currently lower than those of devices with state-of-the art ruthenium(II), organic and zinc porphyrinbased sensitizers, their potential is clear with values of $\eta>3 \%$ with respect to $\eta \sim 7.5 \%$ for the reference ruthenium dye N719. ${ }^{11,12}$

For heteroleptic copper(I) sensitizers, we have demonstrated replacing carboxylic acid anchors with phosphonic acids gives improved DSC performances. ${ }^{\mathbf{1 3}}$ Spacers between the metalbinding and anchoring domains in the anchoring ligand are also relevant, and can enhance photoconversion efficiency of the dye. ${ }^{\mathbf{1 4}}$ We have demonstrated that both phenyl and thiophene spacers are effective; for the latter, improved electron injection is achieved by placing the phosphonic acid group in the 4-rather than the 5-position of the thienyl ring. ${ }^{15}$ The benefits of the thienyl spacer are also supported by Wills et al. ${ }^{16}$ 
<smiles></smiles>

1<smiles>[R]/C(C#N)=C/c1ccc(-c2cc(C)nc(-c3cc(C)nc(-c4ccc(/C=C(/[R])C#N)cc4)c3)c2)cc1</smiles>

$2 \mathrm{R}=\mathrm{CO}_{2} \mathrm{H}$

$3 \mathrm{R}=\mathrm{P}(\mathrm{O})(\mathrm{OH})_{2}$

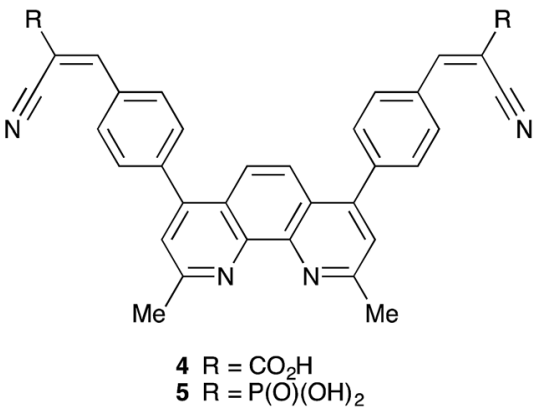

Scheme 1 Structures of the anchoring ligands used in this study.

Anchoring ligand 1 (Scheme 1) has featured in most of our recent studies of copper(I)-based DSCs. Here, we report the effects on the photoconversion efficiencies of DSCs containing $\left[\mathrm{Cu}\left(\mathrm{L}_{\text {anchor }}\right)\left(\mathrm{L}_{\text {ancillary }}\right)\right]^{+}$dyes of replacing the $\mathrm{P}(\mathrm{O})(\mathrm{OH})_{2}$ anchors in $\mathbf{1}$ by cyanoacrylic acid or (1-cyanovinyl)phosphonic acid groups (ligands 2 and 3 , Scheme 1 ). We also look at the effects of replacing the $2,2^{\prime}$-bipyridine (bpy) core by a 1,10 -phenanthroline (phen) domain (ligands 4 and 5, Scheme 1). Each of the anchoring ligands investigated contains methyl groups in the 6,6'-positions of the bpy unit or the 2,9-positions of the phen unit. Substituents in these positions stabilize copper(I) with respect to oxidation to copper(II) by sterically hindering flattening of the tetrahedral coordination sphere to the square planar geometry preferred by copper(II). ${ }^{17}$

\section{Experimental}

\section{General}

A Biotage Initiator 8 microwave reactor was used for reactions carried out under microwave conditions. ${ }^{1} \mathrm{H},{ }^{13} \mathrm{C}$ and ${ }^{31} \mathrm{P}$ NMR spectra were recorded on a Bruker Avance III-500 or $400 \mathrm{MHz}$ NMR spectrometer; ${ }^{1} \mathrm{H}$ and ${ }^{13} \mathrm{C}$ chemical shifts were referenced to residual solvent peaks with respect to $\delta(\mathrm{TMS})=0 \mathrm{ppm}$, and ${ }^{31} \mathrm{P}$ with respect to $\delta\left(85 \%\right.$ aqueous $\left.\mathrm{H}_{3} \mathrm{PO}_{4}\right)=0 \mathrm{ppm}$. Solution and solid state absorption spectra were recorded on an Agilent Cary 5000 UV-Vis-NIR spectrophotometer. FT-IR spectra were recorded using a Perkin Elmer Spectrum Two with UATR for solid samples. MALDI-TOF and electrospray ionization (ESI) mass spectra were recorded on Bruker esquire 3000 plus and Bruker Daltonics Inc. microflex instruments, respectively, and high resolution (HR) ESI-MS on a Bruker maXis $4 \mathrm{G}$ instrument.

Compound $1,{ }^{18} 4,4^{\prime}$-dibromo-6,6'-dimethyl-2,2'-bipyridine, ${ }^{19}$ 4,7-dichloro-2,9-dimethyl-1,10-phenanthroline ${ }^{20}$ and $\left[\mathrm{Cu}\left(\mathrm{Me}_{2}-\right.\right.$ bpy $\left.)_{2}\right]\left[\mathrm{PF}_{6}\right]^{21}$ were prepared as previously described. 6,6'Dimethyl-2,2'-bipyridine ( $\mathrm{Me}_{2} \mathrm{bpy}$ ), (4-formylphenyl)boronic acid and diethyl cyanomethylphosphonate were purchased from Sigma Aldrich, Acros and Alfa Aesar.

\section{4,4'-(6,6'-Dimethyl-[2,2'-bipyridine]-4,4'-diyl)dibenzaldehyde}

The method is adapted from that reported. ${ }^{22} \mathrm{Cs}_{2} \mathrm{CO}_{3}(1.14 \mathrm{~g}$, $3.51 \mathrm{mmol})$ was dissolved in water $(2 \mathrm{~mL})$ and the solution was degassed with $\mathrm{N}_{2}$ for $10 \mathrm{~min}$. 4,4'-Dibromo-6,6'-dimethyl-2,2'bipyridine (200 $\mathrm{mg}, 0.585 \mathrm{mmol}$ ), (4-formylphenyl)boronic acid $(263 \mathrm{mg}, 1.75 \mathrm{mmol})$ and a catalytic amount of $\left[\mathrm{Pd}\left(\mathrm{PPh}_{3}\right)_{4}\right](33.8$ $\mathrm{mg}, 0.090 \mathrm{mmol})$ were dissolved in THF $(15 \mathrm{~mL})$ in a microwave vial and the solution was degassed with $\mathrm{N}_{2}$ for $10 \mathrm{~min}$. The aqueous solution of $\mathrm{Cs}_{2} \mathrm{CO}_{3}$ was then added to the reaction mixture which was then heated at $90{ }^{\circ} \mathrm{C}$ for $4 \mathrm{~h}$ in a microwave reactor. The reaction mixture was allowed to cool to room temperature and then water $(25 \mathrm{~mL})$ was added. The reaction mixture was extracted with $\mathrm{CH}_{2} \mathrm{Cl}_{2}(3 \times 25 \mathrm{~mL})$ and the combined organic layers were dried over $\mathrm{MgSO}_{4}$. The solvent was removed under reduced pressure and the crude product was recrystallized $\left(\mathrm{EtOH} / \mathrm{CHCl}_{3}\right)$. The product was obtained as a white solid ( $170 \mathrm{mg}, 0.433 \mathrm{mmol}, 74.0 \%$ ). The previous literature report of this compound gave only ${ }^{1} \mathrm{H}$ NMR spectroscopic data for a DMSO- $d_{6}$ solution. $.^{22} \mathrm{Mp} 232.2{ }^{\circ} \mathrm{C} .{ }^{1} \mathrm{H}$ NMR $(500 \mathrm{MHz}$, $\mathrm{CDCl}_{3}$ ) $\delta / \mathrm{ppm}: 10.11\left(\mathrm{~s}, 2 \mathrm{H}, \mathrm{H}^{\mathrm{CHO}}\right), 8.55\left(\mathrm{~d}, J=1.3 \mathrm{~Hz}, 2 \mathrm{H}, \mathrm{H}^{\mathrm{A} 5}\right)$, $8.03\left(\mathrm{~m}, 4 \mathrm{H}, \mathrm{H}^{\mathrm{B} 3}\right), 7.92\left(\mathrm{~m}, 4 \mathrm{H}, \mathrm{H}^{\mathrm{B} 2}\right), 7.44(\mathrm{~d}, J=1.3 \mathrm{~Hz}, 2 \mathrm{H}$, $\left.\mathrm{H}^{\mathrm{A} 3}\right), 2.74\left(\mathrm{~s}, 6 \mathrm{H}, \mathrm{H}^{\mathrm{Me}}\right) .{ }^{13} \mathrm{C}\left\{{ }^{1} \mathrm{H}\right\}$ NMR $\left(126 \mathrm{MHz}, \mathrm{CDCl}_{3}\right) \delta / \mathrm{ppm}$ : 191.9 $\left(\mathrm{C}^{\mathrm{CHO}}\right), 159.0\left(\mathrm{C}^{\mathrm{A} 6}\right), 156.6\left(\mathrm{C}^{\mathrm{A} 2}\right), 148.3\left(\mathrm{C}^{\mathrm{B} 1}\right), 144.9\left(\mathrm{C}^{\mathrm{A} 4}\right)$, $136.5\left(\mathrm{C}^{\mathrm{B} 4}\right), 130.5\left(\mathrm{C}^{\mathrm{B} 3}\right), 128.1\left(\mathrm{C}^{\mathrm{B} 2}\right), 121.6\left(\mathrm{C}^{\mathrm{A} 5}\right), 116.9\left(\mathrm{C}^{\mathrm{A} 3}\right), 24.9$ $\left(\mathrm{C}^{\mathrm{Me}}\right)$. ESI-MS positive mode: $m / z 415.04[\mathrm{M}+\mathrm{Na}]^{+}$(calc. 415.14).

\section{Compound 2}

Piperidine $(32.7 \mu \mathrm{L}, 0.331 \mathrm{mmol})$, cyanoacetic acid $(84.5 \mathrm{mg}$, $0.993 \mathrm{mmol})$ and $4,4^{\prime}$-(6,6'-dimethyl-[2,2'-bipyridine]-4,4'-diyl) dibenzaldehyde $(130 \mathrm{mg}, 0.331 \mathrm{mmol})$ were dissolved in $\mathrm{CHCl}_{3}$ $(20 \mathrm{~mL})$ and the reaction mixture was heated at reflux for $\sim 15 \mathrm{~h}$. The reaction mixture was allowed to cool to room temperature and was filtered. The product was washed with $\mathrm{CH}_{2} \mathrm{Cl}_{2}(2 \times 10$ $\mathrm{mL}$ ) to obtain 2 as a white solid (147 $\mathrm{mg}, 0.331 \mathrm{mmol}, 84.3 \%)$. Mp: $234.4^{\circ} \mathrm{C} .{ }^{1} \mathrm{H}$ NMR $\left(500 \mathrm{MHz}\right.$, DMSO- $\left.d_{6}\right) \delta / \mathrm{ppm}: 8.68(\mathrm{br}, 2 \mathrm{H}$, $\left.\mathrm{H}^{\mathrm{OH}}\right), 8.54\left(\mathrm{~s}, 2 \mathrm{H}, \mathrm{H}^{\mathrm{A} 3}\right), 8.31\left(\mathrm{~s}, 2 \mathrm{H}, \mathrm{H}^{\mathrm{a}}\right), 8.17\left(\mathrm{~m}, 4 \mathrm{H}, \mathrm{H}^{\mathrm{B} 3}\right), 8.04$ $\left(\mathrm{m}, 4 \mathrm{H}, \mathrm{H}^{\mathrm{B} 2}\right), 7.75\left(\mathrm{~s}, 2 \mathrm{H}, \mathrm{H}^{\mathrm{A} 5}\right), 2.68\left(\mathrm{~s}, 6 \mathrm{H}, \mathrm{H}^{\mathrm{Me}}\right) \cdot{ }^{13} \mathrm{C}\left\{{ }^{1} \mathrm{H}\right\} \mathrm{NMR}$ $\left(126 \mathrm{MHz}, \mathrm{DMSO}-d_{6}\right) \delta / \mathrm{ppm}: 163.1\left(\mathrm{C}^{\mathrm{COOH}}\right), 158.7\left(\mathrm{C}^{\mathrm{A} 6}\right), 155.5$ $\left(\mathrm{C}^{\mathrm{A} 2}\right), 151.3\left(\mathrm{C}^{\mathrm{a}}\right), 147.2\left(\mathrm{C}^{\mathrm{A} 4}\right), 141.0\left(\mathrm{C}^{\mathrm{B} 1}\right), 132.7\left(\mathrm{C}^{\mathrm{B} 4}\right), 131.1\left(\mathrm{C}^{\mathrm{B} 3}\right)$, $127.6\left(\mathrm{C}^{\mathrm{B} 2}\right), 121.2\left(\mathrm{C}^{\mathrm{A} 5}\right), 117.3\left(\mathrm{C}^{\mathrm{CN}}\right), 115.4\left(\mathrm{C}^{\mathrm{A} 3}\right), 79.2\left(\mathrm{C}^{\mathrm{b}}\right), 24.4$ $\left(\mathrm{C}^{\mathrm{Me}}\right)$. IR (solid, $\left.\tilde{v} / \mathrm{cm}^{-1}\right)$ : $~ 3000(\mathrm{v} \mathrm{br}), 2218(\mathrm{w}), 1710(\mathrm{~m}), 1595$ (s), $1543(\mathrm{~m}), 1382(\mathrm{~m}), 1340(\mathrm{~m}), 1275(\mathrm{~m}), 1215(\mathrm{~m}), 1191(\mathrm{~s})$, 830 (vs.), 754 (s), 717 (vs.). ESI-MS positive mode: $m / z 527.07$ [M $+\mathrm{H}]^{+}$(calc. 527.17). HR ESI-MS: $m / z 527.1713[\mathrm{M}+\mathrm{H}]^{+}$(calc. 
527.1714). Satisfactory elemental analysis could not be obtained.

\section{Ester 3a}

Piperidine (7.91 $\mu \mathrm{L}, 0.080 \mathrm{mmol})$, diethyl cyanomethylphosphonate $(38.6 \mu \mathrm{L}, 0.240 \mathrm{mmol})$ and $4,4^{\prime}$-(6,6'-dimethyl-[2,2'-bipyridine]-4,4'-diyl)dibenzaldehyde $(31.4 \mathrm{mg}, 0.080 \mathrm{mmol})$ were dissolved in $\mathrm{CHCl}_{3}(20 \mathrm{~mL})$ and the reaction mixture was heated at reflux for $\sim 15 \mathrm{~h}$. The reaction mixture was allowed to cool to room temperature and $\mathrm{CH}_{2} \mathrm{Cl}_{2}(30 \mathrm{~mL})$ was added. The organic layer was washed with water $(3 \times 25 \mathrm{~mL})$ and brine $(3 \times 25 \mathrm{~mL})$, dried over $\mathrm{MgSO}_{4}$ and the solvent was removed under reduced pressure. The crude product was purified by column chromatography ( $3: 2$ cyclohexane/acetone) and the solvent from the fraction collected was removed under reduced pressure. Ester 3a was isolated as a white solid (44.6 $\mathrm{mg}, 0.0628 \mathrm{mmol}, 78.4 \%)$. ${ }^{1} \mathrm{H}$ NMR $\left(500 \mathrm{MHz}, \mathrm{CDCl}_{3}\right) \delta / \mathrm{ppm}: 8.55\left(\mathrm{~d}, J=1.2 \mathrm{~Hz}, 2 \mathrm{H}, \mathrm{H}^{\mathrm{A} 3}\right)$, $8.11\left(\mathrm{~m}, 4 \mathrm{H}, \mathrm{H}^{\mathrm{B} 3}\right), 8.07\left(\mathrm{~d}, J_{\mathrm{PH}} \sim 21 \mathrm{~Hz}, 2 \mathrm{H}, \mathrm{H}^{\mathrm{a}}\right), 7.90(\mathrm{~m}, 4 \mathrm{H}$, $\left.\mathrm{H}^{\mathrm{B} 2}\right), 7.44\left(\mathrm{~d}, J=1.3 \mathrm{~Hz}, 2 \mathrm{H}, \mathrm{H}^{\mathrm{A} 5}\right), 4.27\left(\mathrm{~m}, 8 \mathrm{H}, \mathrm{H}^{\mathrm{Et}}\right), 2.74(\mathrm{~s}, 6 \mathrm{H}$, $\left.\mathrm{H}^{\mathrm{Me}-\mathrm{bpy}}\right), 1.44\left(\mathrm{~m}, 12 \mathrm{H}, \mathrm{H}^{\mathrm{Et}}\right) .{ }^{13} \mathrm{C}\left\{{ }^{1} \mathrm{H}\right\} \mathrm{NMR}\left(126 \mathrm{MHz}, \mathrm{CDCl}_{3}\right) \delta /$ ppm: $159.0\left(\mathrm{C}^{\mathrm{A} 6}\right), 158.0\left(\mathrm{~d}, J_{\mathrm{PC}}=6.7 \mathrm{~Hz}, \mathrm{C}^{\mathrm{a}}\right), 156.6\left(\mathrm{C}^{\mathrm{A} 2}\right), 147.9$ $\left(\mathrm{C}^{\mathrm{A} 4}\right), 143.3\left(\mathrm{C}^{\mathrm{B} 1}\right), 132.9\left(\mathrm{C}^{\mathrm{B} 4}\right), 131.4\left(\mathrm{C}^{\mathrm{B} 3}\right), 128.2\left(\mathrm{C}^{\mathrm{B} 2}\right), 121.4$ $\left(\mathrm{C}^{\mathrm{A} 5}\right), 116.8\left(\mathrm{C}^{\mathrm{A} 3}\right), 115.6\left(\mathrm{C}^{\mathrm{CN}}\right), 63.9\left(\mathrm{~d}, J_{\mathrm{PC}}=5.8 \mathrm{~Hz}, \mathrm{C}^{\mathrm{Et}}\right), 24.4$ $\left(\mathrm{C}^{\text {Me-bpy }}\right), 16.4\left(\mathrm{~d}, J_{\mathrm{PC}}=6.4 \mathrm{~Hz}, \mathrm{C}^{\mathrm{Et}}\right)$, signal for $\mathrm{C}^{\mathrm{b}}$ was not resolved. ${ }^{31} \mathrm{P}\left\{{ }^{1} \mathrm{H}\right\}$ NMR (202 $\left.\mathrm{MHz}, \mathrm{CDCl}_{3}\right) \delta / \mathrm{ppm}$ : +10.9. ESI-MS: $m / z 711.12[\mathrm{M}+\mathrm{H}]^{+}$(calc. 711.25). HR ESI-MS positive mode: $\mathrm{m} / \mathrm{z}$ 711.2497 $[\mathrm{M}+\mathrm{H}]^{+}$(calc. 711.2496). Satisfactory elemental analysis could not be obtained.

\section{Compound 3}

$\mathrm{Me}_{3} \mathrm{SiBr}(0.639 \mathrm{~mL}, 4.84 \mathrm{mmol})$ and $3 \mathrm{a}(44.6 \mathrm{mg}, 0.0628 \mathrm{mmol})$ were dissolved in $\mathrm{CH}_{2} \mathrm{Cl}_{2}(20 \mathrm{~mL})$. The reaction mixture was stirred for 2.5 days at room temperature. Water $(20 \mathrm{~mL})$ was added to the reaction mixture and a precipitate formed. The product was filtered, and washed with water $(10 \mathrm{~mL})$, EtOH $(2 \times$ $10 \mathrm{~mL})$ and $\mathrm{CH}_{2} \mathrm{Cl}_{2}(2 \times 10 \mathrm{~mL})$. Compound 3 was isolated as a pale yellow solid (13.3 mg, $0.022 \mathrm{mmol}, 35.0 \%) .{ }^{1} \mathrm{H}$ NMR (500 MHz, DMSO- $\left.d_{6}\right) \delta /$ ppm: $8.81\left(\mathrm{~d}, J=1.8 \mathrm{~Hz}, 2 \mathrm{H} \mathrm{H}^{\mathrm{A} 3}\right), 8.22(\mathrm{~m}, 4 \mathrm{H}$, $\left.\mathrm{H}^{\mathrm{B} 2}\right), 8.17\left(\mathrm{~m}, 4 \mathrm{H}, \mathrm{H}^{\mathrm{B} 3}\right), 8.15\left(\mathrm{~s}, 2 \mathrm{H}, \mathrm{H}^{\mathrm{A} 5}\right), 7.99(\mathrm{~d}, J=19.7 \mathrm{~Hz}$, $\left.2 \mathrm{H}, \mathrm{H}^{\mathrm{a}}\right), 2.82\left(\mathrm{~s}, 6 \mathrm{H}, \mathrm{H}^{\mathrm{Me}}\right) .{ }^{13} \mathrm{C}\left\{{ }^{1} \mathrm{H}\right\}$ NMR $\left(126 \mathrm{MHz}\right.$, DMSO- $\left.d_{6}\right) \delta /$ ppm: $157.88\left(\mathrm{C}^{\mathrm{A} 6}\right), 152.9\left(\mathrm{~d}, J=6.1 \mathrm{~Hz} \mathrm{C}^{\mathrm{a}}\right), 149.8\left(\mathrm{C}^{\mathrm{A} 4}\right), 138.7$ $\left(\mathrm{C}^{\mathrm{B} 1}\right), 134.6\left(\mathrm{C}^{\mathrm{B} 4}\right), 130.3\left(\mathrm{C}^{\mathrm{B} 3}\right), 128.3\left(\mathrm{C}^{\mathrm{B} 2}\right), 123.6\left(\mathrm{C}^{\mathrm{A} 5}\right), 118.4$ $\left(\mathrm{C}^{\mathrm{A} 3}\right), 116.7\left(\mathrm{C}^{\mathrm{CN}}\right), 107.6\left(\mathrm{~d}, J_{\mathrm{PC}}=182.9 \mathrm{~Hz}, \mathrm{C}^{\mathrm{b}}\right), 22.6\left(\mathrm{C}^{\mathrm{Me}}\right)$; signal for $\mathrm{H}^{\mathrm{A} 3}$ was not resolved. ${ }^{31} \mathrm{P}\left\{{ }^{1} \mathrm{H}\right\}$ NMR $(202 \mathrm{MHz}$, DMSO$\left.d_{6}\right) \delta / \mathrm{ppm}:+4.55$. IR (solid, $\tilde{\nu} / \mathrm{cm}^{-1}$ ): $\sim 3000(\mathrm{br}), 2209(\mathrm{w}), 1623$ (sh), 1597 (s), 1394 (m), 1163 (sh), 1050 (s), 920 (s), 828 (vs.), 616 (s) 564 (vs.). MALDI-MS: $m / z 599.07[\mathrm{M}+\mathrm{H}]^{+}$(calc. 559.12). ESIMS negative mode: (3 in aqu. $\mathrm{NH}_{3}$ ) $m / z 297.88[\mathrm{M}-2 \mathrm{H}]^{2-}$ (calc. 298.05). HR ESI-MS: $m / z$ 298.0515 $[\mathrm{M}-2 \mathrm{H}]^{2-}$ (calc. 298.0513). Satisfactory elemental analysis could not be obtained.

\section{4,4'-(2,9-Dimethyl-1,10-phenanthroline-4,7-diyl) dibenzaldehyde}

$\mathrm{Cs}_{2} \mathrm{CO}_{3}$ (3.52 g, $\left.10.8 \mathrm{mmol}\right)$ was dissolved in water $(2 \mathrm{~mL})$ and the solution degassed with $\mathrm{N}_{2}$ for $10 \mathrm{~min}$. 4,7-Dichloro-2,9dimethyl-1,10-phenanthroline $(500 \mathrm{mg}, 1.80 \mathrm{mmol}), \quad$ (4- formylphenyl)boronic acid ( $810 \mathrm{mg}, 5.40 \mathrm{mmol}$ ) and a catalytic amount of $\left[\mathrm{Pd}\left(\mathrm{PPh}_{3}\right)_{4}\right](104 \mathrm{mg}, 0.090 \mathrm{mmol})$ were dissolved in THF (15 mL) in a microwave vial and the solution was degassed with $\mathrm{N}_{2}$ for $10 \mathrm{~min}$. The aqueous solution was then added to the THF solution and the reaction was heated at $90{ }^{\circ} \mathrm{C}$ for $4 \mathrm{~h}$ in a microwave reactor. After the mixture had cooled to ambient temperature, water $(25 \mathrm{~mL})$ was added. The mixture was extracted with $\mathrm{CH}_{2} \mathrm{Cl}_{2}(3 \times 25 \mathrm{~mL})$ and the combined organic layers were dried over $\mathrm{MgSO}_{4}$. Solvent was then removed under reduced pressure and the crude product was recrystallized from EtOH/ $\mathrm{CHCl}_{3}$. 4,4'-(2,9-Dimethyl-1,10-phenanthroline-4,7-diyl) dibenzaldehyde was isolated as a pale yellow solid $(90.1 \mathrm{mg}$, $0.216 \mathrm{mmol}, 12.0 \%)$. Decomp > $300{ }^{\circ} \mathrm{C}$. ${ }^{1} \mathrm{H}$ NMR $(500 \mathrm{MHz}$, $\mathrm{CDCl}_{3}$ ) $\delta /$ ppm: $10.13\left(\mathrm{~s}, 2 \mathrm{H}, \mathrm{H}^{\mathrm{CHO}}\right), 8.04\left(\mathrm{~d}, 4 \mathrm{H}, J=8.3 \mathrm{~Hz}, \mathrm{H}^{\mathrm{B} 3}\right)$, $7.70\left(\mathrm{~d}, 4 \mathrm{H}, J=8.3, \mathrm{H}^{\mathrm{B} 2}\right), 7.68\left(\mathrm{~s}, 2 \mathrm{H}, \mathrm{H}^{\mathrm{A} 5}\right), 7.48\left(\mathrm{~s}, 2 \mathrm{H}, \mathrm{H}^{\mathrm{A} 3}\right), 3.01$ $\left(\mathrm{s}, 6 \mathrm{H}, \mathrm{H}^{\mathrm{Me}}\right) \cdot{ }^{13} \mathrm{C}\left\{{ }^{1} \mathrm{H}\right\}$ NMR $\left(126 \mathrm{MHz}, \mathrm{CDCl}_{3}, \delta / \mathrm{ppm}\right): 191.8$ $\left(\mathrm{C}^{\mathrm{CHO}}\right), 159.3\left(\mathrm{C}^{\mathrm{A} 2}\right), 147.3\left(\mathrm{C}^{\mathrm{A} 4}\right), 146.1\left(\mathrm{C}^{\mathrm{A} 10 \mathrm{a}}\right), 144.4\left(\mathrm{C}^{\mathrm{B} 1}\right), 136.2$ $\left(\mathrm{C}^{\mathrm{B} 4}\right), 130.5\left(\mathrm{C}^{\mathrm{B} 2}\right), 136.0\left(\mathrm{C}^{\mathrm{B} 3}\right), 124.4\left(\mathrm{C}^{\mathrm{A} 4 \mathrm{a}}\right), 124.0\left(\mathrm{C}^{\mathrm{A} 3}\right), 123.0$ $\left(\mathrm{C}^{\mathrm{A} 5}\right), 26.1\left(\mathrm{C}^{\mathrm{Me}}\right)$. ESI-MS positive mode: $m / z$ 417.06 $[\mathrm{M}+\mathrm{H}]^{+}$ (calc. 417.16), $439.04[\mathrm{M}+\mathrm{Na}]^{+}$(calc. 439.04).

\section{Compound 4}

Piperidine $(14.3 \mu \mathrm{L}, 0.145 \mathrm{mmol})$, cyanoacetic acid $(37.0 \mathrm{mg}$, $0.435 \mathrm{mmol}$ ) and 4,4'-(2,9-dimethyl-1,10-phenanthroline-4,7diyl)dibenzaldehyde $(60.3 \mathrm{mg}, 0.145 \mathrm{mmol})$ were dissolved in $\mathrm{CHCl}_{3}(20 \mathrm{~mL})$ and the reaction mixture was heated at reflux for $\sim 15 \mathrm{~h}$. The reaction mixture was allowed to cool down to room temperature, then was filtered and the solid product was washed with $\mathrm{CH}_{2} \mathrm{Cl}_{2}(2 \times 10 \mathrm{~mL})$. Compound 4 was isolated as a pale yellow solid (55.7 mg, $0.101 \mathrm{mmol}, 69.8 \%$ ). Decomp > 300 ${ }^{\circ} \mathrm{C} .{ }^{1} \mathrm{H}$ NMR $\left(500 \mathrm{MHz}, \mathrm{DMSO}-d_{6}\right) \delta / \mathrm{ppm}: 8.44\left(\mathrm{~s}, 2 \mathrm{H} \mathrm{H}^{\mathrm{a}}\right), 8.23(\mathrm{~d}$, $\left.J=8.4 \mathrm{~Hz}, 4 \mathrm{H}, \mathrm{H}^{\mathrm{B} 3}\right), 7.80\left(\mathrm{~d}, J=8.4 \mathrm{~Hz}, 4 \mathrm{H}, \mathrm{H}^{\mathrm{B} 2}\right), 7.75(\mathrm{~s}, 2 \mathrm{H}$, $\left.\left.\mathrm{H}^{\mathrm{A} 3}\right), 7.67\left(\mathrm{~s}, 2 \mathrm{H}, \mathrm{H}^{\mathrm{A} 5}\right), 2.87\left(\mathrm{~s}, 6 \mathrm{H}, \mathrm{H}^{\mathrm{Me}}\right) .{ }^{13} \mathrm{C}^{1}{ }^{1} \mathrm{H}\right\}$ NMR $(126$ MHz, DMSO- $\left.d_{6}\right) \delta /$ ppm: $163.0\left(\mathrm{C}^{\mathrm{COOH}}\right), 158.1\left(\mathrm{C}^{\mathrm{A} 2}\right), 153.0\left(\mathrm{C}^{\mathrm{a}}\right)$, $146.3\left(\mathrm{C}^{\mathrm{A} 4}\right), 145.4\left(\mathrm{C}^{\mathrm{A} 10 \mathrm{a}}\right), 141.7\left(\mathrm{C}^{\mathrm{B} 1}\right), 131.7\left(\mathrm{C}^{\mathrm{B} 4}\right), 130.7\left(\mathrm{C}^{\mathrm{B} 3}\right)$, $130.3\left(\mathrm{C}^{\mathrm{B} 2}\right), 123.7\left(\mathrm{C}^{\mathrm{A} 5}\right), 122.6\left(\mathrm{C}^{\mathrm{A} 3}\right), 116.8\left(\mathrm{C}^{\mathrm{CN}}\right), 24.8\left(\mathrm{C}^{\mathrm{Me}}\right)$; signals for $\mathrm{C}^{\mathrm{b}}, \mathrm{C}^{4 \mathrm{a}}$ were not resolved. IR $\left(\tilde{\nu} / \mathrm{cm}^{-1}\right): \sim 3000(\mathrm{br})$, 2218 (w), 1703 (m), 1598 (vs.), 1554 (m), 1328 (m), 1259 (m), 1190 (s), 838 (vs.), 711 (vs.). MALDI-MS: $m / z 551.34[\mathrm{M}+\mathrm{H}]^{+}$(calc. 551.17). ESI-MS positive mode: $m / z$ 551.08 $[\mathrm{M}+\mathrm{H}]^{+}$(calc. 551.17). High resolution ESI-MS: $m / z 551.1712[\mathrm{M}+\mathrm{H}]^{+}$(calc. 551.1714). Satisfactory elemental analysis could not be obtained.

\section{Ester 5a}

Piperidine (16.8 $\mu \mathrm{L}, 0.170 \mathrm{mmol})$, diethyl cyanomethylphosphonate (82.1 $\mu \mathrm{L}, \quad 0.510 \mathrm{mmol}$ ) and (dimethyl-1,10phenanthroline-4,7-diyl)dibenzaldehyde $\quad\left(\begin{array}{llll}70.7 & \mathrm{mg}, & 0.170\end{array}\right.$ mmol) were dissolved in $\mathrm{CHCl}_{3}(20 \mathrm{~mL})$ and the reaction mixture was heated at reflux for $\sim 15 \mathrm{~h}$. After cooling the mixture to room temperature, $\mathrm{CH}_{2} \mathrm{Cl}_{2}(30 \mathrm{~mL})$ was added and the organic layer was washed with water $(3 \times 25 \mathrm{~mL})$ followed by brine $(3 \times 25 \mathrm{~mL})$, dried over $\mathrm{MgSO}_{4}$ and the solvent was removed under reduced pressure. The crude product was purified by column chromatography ( $3: 2$ cyclohexane/acetone) and the solvent from the fractions collected was removed under 
reduced pressure. Ester 5a was isolated as a pale yellow solid (61.4 mg, $0.0836 \mathrm{mmol}, 49.2 \%) .{ }^{1} \mathrm{H} \mathrm{NMR}\left(500 \mathrm{MHz}, \mathrm{CDCl}_{3}, \delta /\right.$ ppm) $8.11\left(\mathrm{~m}, 6 \mathrm{H}, \mathrm{H}^{\mathrm{B} 3+\mathrm{a}}\right), 7.71\left(\mathrm{~s}, 2 \mathrm{H}, \mathrm{H}^{\mathrm{A} 5}\right), 7.67(\mathrm{~d}, 4 \mathrm{H}, J=8.2$ $\left.\mathrm{Hz}, \mathrm{H}^{\mathrm{B} 2}\right), 7.47\left(\mathrm{~s}, 2 \mathrm{H}, \mathrm{H}^{\mathrm{A} 3}\right), 4.27\left(\mathrm{~m}, 8 \mathrm{H}, \mathrm{H}^{\mathrm{Et}}\right), 3.02\left(\mathrm{~s}, 6 \mathrm{H}, \mathrm{H}^{\mathrm{Me}-}\right.$ phen $), 1.44$ (t, 12H, 7.2 Hz, H $\left.{ }^{\mathrm{Et}}\right) .{ }^{13} \mathrm{C}\left\{{ }^{1} \mathrm{H}\right\} \mathrm{NMR}\left(126 \mathrm{MHz}, \mathrm{CDCl}_{3}\right)$

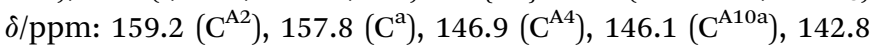
$\left(\mathrm{C}^{\mathrm{B} 1}\right), 132.5\left(\mathrm{C}^{\mathrm{B} 4}\right), 130.6\left(\mathrm{C}^{\mathrm{B} 3}\right), 130.5\left(\mathrm{C}^{\mathrm{B} 2}\right), 124.2\left(\mathrm{C}^{\mathrm{A} 4 \mathrm{a}}\right), 123.9$ $\left(\mathrm{C}^{\mathrm{A} 3}\right), 122.9\left(\mathrm{C}^{\mathrm{A} 5}\right), 115.3\left(\mathrm{C}^{\mathrm{CN}}\right), 101.2\left(\mathrm{~d}, J_{\mathrm{PC}}=258 \mathrm{~Hz}, \mathrm{C}^{\mathrm{b}}\right), 63.9$ $\left(\mathrm{d}, J_{\mathrm{PC}}=5.8 \mathrm{~Hz}, \mathrm{C}^{\mathrm{Et}}\right), 26.0\left(\mathrm{C}^{\mathrm{Me}-\mathrm{bpy}}\right), 16.5\left(\mathrm{~d}, J_{\mathrm{PC}}=6.3 \mathrm{~Hz}, \mathrm{C}^{\mathrm{Et}}\right)$. ${ }^{31} \mathrm{P}\left\{{ }^{1} \mathrm{H}\right\}$ NMR (202 MHz, $\mathrm{CDCl}_{3}$ ) $\delta / \mathrm{ppm}:+10.7$. ESI-MS positive mode: $m / z 735.1[\mathrm{M}+\mathrm{H}]^{+}$(calc. 735.25). HR ESI-MS: $m / z$ 735.2500 $[\mathrm{M}+\mathrm{H}]^{+}$(calc. 735.2496). Satisfactory elemental analysis could not be obtained.

\section{Compound 5}

$\mathrm{Me}_{3} \mathrm{SiBr}(0.718 \mathrm{~mL}, 5.44 \mathrm{mmol})$ and $5 \mathrm{a}(61.4 \mathrm{mg}, 0.0836 \mathrm{mmol})$ were dissolved in $\mathrm{CH}_{2} \mathrm{Cl}_{2}(20 \mathrm{~mL})$ and the reaction mixture was stirred for 3 days at room temperature. Water $(20 \mathrm{~mL})$ was added to the reaction mixture and the precipitate that formed was collected by filtration, and was washed with water $(10 \mathrm{~mL})$, EtOH $(2 \times 10 \mathrm{~mL})$ and $\mathrm{CH}_{2} \mathrm{Cl}_{2}(2 \times 10 \mathrm{~mL}) .5$ was isolated as a pale yellow solid (26.3 $\mathrm{mg}, 0.0422 \mathrm{mmol}, 50.5 \%$ ). Only a broadened ${ }^{1} \mathrm{H}$ NMR spectrum could be recorded (see text discussion). MALDI-MS: $m / z 622.92\left[\mathrm{M}+\mathrm{H}^{+}\right]$(calc. 623.12). ESIMS negative mode: ( 5 in aqu. $\mathrm{NH}_{3}$ ): $m / z 309.95[\mathrm{M}-2 \mathrm{H}]^{2-}$ (calc. 310.05). HR ESI-MS: $m / z 310.0514[\mathrm{M}-2 \mathrm{H}]^{2-}$ (calc. 310.0513). IR ( $\left.\tilde{\nu} / \mathrm{cm}^{-1}\right)$ : $~ 3000(\mathrm{br}), 2206(\mathrm{w}), 1616(\mathrm{~s}), 1597(\mathrm{~s}), 1557(\mathrm{~m})$, 1402 (w), 1158 (sh), 1062 (vs.), 920 (s), 838 (vs.), 622 (s) 566 (vs.). Satisfactory elemental analysis could not be obtained.

\section{Electrodes for solid-state absorption spectroscopy}

Dye-functionalized electrodes were assembled as detailed below but using Solaronix Test Cell Titania Electrodes Transparent.

\section{DSC fabrication and measurements}

Working electrodes (Solaronix Test Cell Titania Electrodes) were washed with milliQ water and EtOH and sintered at $450{ }^{\circ} \mathrm{C}$ for $30 \mathrm{~min}$, then cooled to $\approx 80{ }^{\circ} \mathrm{C}$ and immersed in a DMSO solution of $1,2,3,4$ or $5(1.0 \mathrm{mM})$ for $24 \mathrm{~h}$ at room temperature. The functionalized electrodes were removed from the solutions, washed with DMSO and EtOH and dried using a heat gun (100 ${ }^{\circ} \mathrm{C}$ ). Each electrode was then immersed for 3 days in an acetone solution of $\left[\mathrm{Cu}(6)_{2}\right]\left[\mathrm{PF}_{6}\right]$ or $\left[\mathrm{Cu}(7)_{2}\right]\left[\mathrm{PF}_{6}\right](0.1 \mathrm{mM})$; during this period, the $\mathrm{TiO}_{2}$ area on each electrode turned red-orange. After removal from the dye-bath, electrodes were washed with acetone and dried with a heat gun $\left(80^{\circ} \mathrm{C}\right)$. An N719 reference electrode was made by dipping a Solaronix Test Cell Titania Electrode in a EtOH solution (0.3 mM) of N719 (Solaronix) for 3 days. After taking it out of the dye-bath, the electrode was washed with EtOH and dried with a heat gun $\left(80^{\circ} \mathrm{C}\right)$. Solaronix Test Cell Platinum Electrodes were used for the counter electrodes, and volatile organic impurities were removed by placing the electrodes on a heating plate $\left(450{ }^{\circ} \mathrm{C}, 30 \mathrm{~min}\right)$.

The working and counter electrodes were joined using thermoplast hot-melt sealing foil (Solaronix Test Cell Gaskets) by heating while pressing them together. The electrolyte comprised LiI (0.1 M), I 2 (0.05 M), 1-methylbenzimidazole (0.5 M), 1-butyl-3-methylimidazolinium iodide $(0.6 \mathrm{M})$ in 3methoxypropionitrile. The electrolyte was introduced into the DSC by vacuum backfilling and then the hole in the counter electrode was sealed (Solaronix Test Cell Sealings) and covered (Solaronix Test Cell Caps).

Measurements were made by irradiating from behind using a light source LOT Quantum Design LS0811 (100 $\mathrm{mW} \mathrm{cm}^{-2}=1$ sun). The power of the simulated light was calibrated using a reference Si cell. All DSCs were completely masked ${ }^{23,24}$ before measurements were made.

The external quantum efficiency (EQE) measurements were made using a Spe-Quest quantum efficiency setup (Rera Systems, Netherlands) operating with a $100 \mathrm{~W}$ halogen lamp (QTH) and a lambda 300 grating monochromator (Lot Oriel). The monochromatic light was modulated to $3 \mathrm{~Hz}$ using a chopper wheel (ThorLabs), and the cell response was amplified with a large dynamic range IV converter (CVI Melles Griot) and then measured with a SR830 DSP Lock-In amplifier (Stanford Research).

Electrochemical impedance spectroscopy (EIS) measurements were carried out on a ModuLab ${ }^{\circledR}$ XM PhotoEchem photoelectrochemical measurement system from Solartron Analytical. The impedance was measured around the opencircuit potential of the cell at different light intensities (590 $\mathrm{nm}$ ) in the frequency range $0.05 \mathrm{~Hz}$ to $100 \mathrm{kHz}$ using an amplitude of $10 \mathrm{mV}$. The impedance data were analysed using ZView ${ }^{\circledR}$ software from Scribner Associates Inc.

\section{Results and discussion}

\section{Anchoring ligand syntheses}

The procedures for the preparation of ligands 2 and 3 are summarized in Scheme 2. Ligand 2 has previously been reported, and we adapted the method described by Yuan et al., ${ }^{22}$ using (4-formylphenyl)boronic acid in place of the analogous pinacolate ester in the first step. The 4,7-functionalized phen compounds 4 and 5 were prepared in an analogous manner to the routes shown for 2 and 3, but replacing 4,4'-dibromo-6, $6^{\prime}$ dimethyl-2,2'-bipyridine by 4,7-dichloro-2,9-dimethyl-1,10phenanthroline.

The intermediates $4,4^{\prime}$-(6,6'-dimethyl-[2,2'-bipyridine $]-4,4^{\prime}$ diyl)dibenzaldehyde and 4,4'-(2,9-dimethyl-1,10-phenanthroline4,7-diyl)dibenzaldehyde were characterized by ${ }^{1} \mathrm{H}$ and ${ }^{13} \mathrm{C}$ NMR spectroscopies and mass spectrometry (see Experimental section). Treatment of these aldehydes with cyanoacetic acid in the presence of piperidine (Scheme 2) yielded the cyanoacrylic acids 2 and 4 (Scheme 1) in 84.3 and 69.8\% yield, respectively, after workup. The base peak in the electrospray (ESI) mass spectrum of 2 was observed at $m / z 527.07$ corresponding to [ $\mathrm{M}+$ $\mathrm{H}]^{+}$. For 4 , the $[\mathrm{M}+\mathrm{H}]^{+}$peak appeared at $m / z 551.34$ in the MALDI-TOF mass spectrum, but was not observed using ESI MS. The IR spectra of 2 and $\mathbf{4}$ are shown in Fig. $\mathrm{S} 1$. $\dagger$ The $\mathrm{C} \equiv \mathrm{N}$ group gives rise to a band at $2218 \mathrm{~cm}^{-1}$ both in 2 and 4 ; strong absorptions at $1595 \mathrm{~cm}^{-1}$ in 2 and $1598 \mathrm{~cm}^{-1}$ in 4 are characteristic of the carboxylic acid group. COSY, HMQC, HMBC and NOESY methods were used to assign the ${ }^{1} \mathrm{H}$ and ${ }^{13} \mathrm{C}$ NMR spectra 
<smiles>Cc1cc(Br)cc(-c2cc(Br)cc(C)n2)n1</smiles><smiles>Cc1cc(-c2ccc(C=O)cc2)cc(-c2cc(-c3ccc(C(=O)C(C)(C)C)cc3)cc(C)n2)n1</smiles>

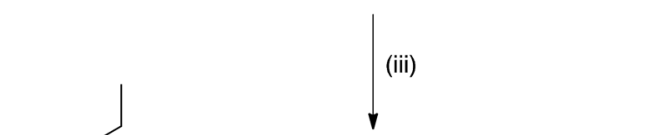

2<smiles>CCOP(=O)(OCC)C(C#N)=Cc1ccc(-c2cc(C)nc(-c3cc(-c4ccc(C=C(C#N)P(=O)(OCC)OCC)cc4)cc(C)n3)c2)cc1</smiles>

Scheme 2 Synthetic route to compounds 2 and 3. Conditions: (i) $\mathrm{Pd}\left(\mathrm{PPh}_{3}\right)_{4}\left(0.05\right.$ mol\%), $\mathrm{Cs}_{2} \mathrm{CO}_{3}, \mathrm{THF} / \mathrm{H}_{2} \mathrm{O}$, microwave reactor, $90{ }^{\circ} \mathrm{C}, 4 \mathrm{~h}$; (ii) cyanoacetic acid, piperidine, $\mathrm{CHCl}_{3}, 70{ }^{\circ} \mathrm{C}, 16 \mathrm{~h}$; (iii) diethyl cyanomethylphosphonate, piperidine, $\mathrm{CHCl}_{3}, 70{ }^{\circ} \mathrm{C}, 16 \mathrm{~h}$; (iv) $\mathrm{Me}_{3} \mathrm{SiBr}, \mathrm{CH}_{2} \mathrm{Cl}_{2}, \mathrm{room}$ temperature, $56 \mathrm{~h}$. Atom labelling is used for the NMR assignments of 2 and 3; synthetic routes to 4 and 5 are analogous to those for 2 and 3 , and atom labelling for 4 and 5 is given in Scheme S1. $\uparrow$

of 2 and 4. Assignments of $\mathrm{H}^{\mathrm{B} 2}$ and $\mathrm{H}^{\mathrm{B} 3}$, and of $\mathrm{H}^{\mathrm{A} 3}$ and $\mathrm{H}^{\mathrm{A} 5}$ in 2 (see Scheme 2 for atom labels) were made on the basis of NOESY cross-peaks between $\mathrm{H}^{\mathrm{a}} / \mathrm{H}^{\mathrm{B} 3}, \mathrm{H}^{\mathrm{A} 3 / \mathrm{A} 5} \mathrm{H}^{\mathrm{B} 3}$ and $\mathrm{H}^{\mathrm{A} 5} / \mathrm{H}^{\mathrm{Me}}$. The stereochemistry about the $\mathrm{C}=\mathrm{C}$ bond drawn in Scheme 1 is preferred, ${ }^{25}$ and for 2 , the lack of a NOESY peak between $\mathrm{H}^{\mathrm{OH}}$ and $\mathrm{H}^{\mathrm{B} 3}$ is consistent with this configuration. A search of the Cambridge Structural Database ${ }^{26,27}$ using Conquest ${ }^{28}$ v. 5.37 (with November 2015 update) revealed only 17 hits for compounds containing a $\mathrm{C}_{6} \mathrm{H}_{4} \mathrm{CH}=(\mathrm{CN})\left(\mathrm{CO}_{2} \mathrm{H}\right)$ fragment and all possess the configuration shown in Scheme 1. Kloo and coworkers have demonstrated that photoisomerization of the unit can occur. ${ }^{25}$

The aldehyde intermediates were converted into the (1-cyanovinyl)phosphonic acids in two steps. 4,4'-(6,6'-Dimethyl-[2,2'bipyridine]-4,4'-diyl)dibenzaldehyde or $4,4^{\prime}$-(2,9-dimethyl-1,10phenanthroline-4,7-diyl)dibenzaldehyde was treated with diethyl cyanomethylphosphonate in the presence of piperidine to yield esters $\mathbf{3 a}$ (Scheme 2) or $\mathbf{5 a}$, respectively. These compounds were deprotected with $\mathrm{Me}_{3} \mathrm{SiBr}$ to yield phosphonic acids 3 and 5. Despite several attempts, satisfactory elemental analyses of $\mathbf{3 a}, \mathbf{5 a}, \mathbf{3}$ and $\mathbf{5}$ could not be obtained, probably due to the presence of water. The base peaks in the high resolution electrospray mass spectra of esters $3 \mathbf{a}$ or $\mathbf{5 a}$ came at $\mathrm{m} / \mathrm{z}$ 711.2497 and 735.2500 , respectively, corresponding to the $[\mathrm{M}+$ $\mathrm{H}]^{+}$ions. For acids 3 and 5, MALDI mass spectra exhibited ions at $\mathrm{m} / \mathrm{z} 599.07$ and 622.92 , respectively, arising from $[\mathrm{M}+\mathrm{H}]^{+}$. ESI-MS and HR ESI-MS could only be obtained by using a solution of $\mathbf{3}$ or $\mathbf{5}$ in dilute aqueous $\mathrm{NH}_{3}$ with the instrument in negative mode. Under these conditions, base peaks corresponding to $[\mathrm{M}-2 \mathrm{H}]^{2-}$ were obtained (see Experimental section). The IR spectra of $\mathbf{3}$ and $\mathbf{5}$ (Fig. S2 $\dagger$ ) demonstrate the presence of the $\mathrm{C} \equiv \mathrm{N}$ group with bands at $2209 \mathrm{~cm}^{-1}$ in 3 and $2206 \mathrm{~cm}^{-1}$ in 5 .

Each of 3a and 5a was characterized by ${ }^{1} \mathrm{H},{ }^{13} \mathrm{C}$ and ${ }^{31} \mathrm{P}$ NMR spectroscopies, and assignments of ${ }^{1} \mathrm{H}$ and ${ }^{13} \mathrm{C}$ resonances were made using routine $2 \mathrm{D}$ methods. The ${ }^{31} \mathrm{P}$ NMR spectrum of $3 \mathbf{a}$ showed a singlet at $\delta+10.9 \mathrm{ppm}$, close to that $(\delta+10.7 \mathrm{ppm})$ observed for $5 \mathbf{a}$. In the ${ }^{1} \mathrm{H}$ NMR spectrum of $\mathbf{3 a}$, the signal for vinylic $\mathrm{H}^{\mathrm{a}}$ appears as a doublet $\left(\mathrm{J}_{\mathrm{PH}} \sim 21 \mathrm{~Hz}\right.$, see Fig. $\mathrm{S} 3 \dagger$ ) (and similarly, in the ${ }^{13} \mathrm{C}\left\{{ }^{1} \mathrm{H}\right\}$ NMR, the signal for $\mathrm{C}^{\mathrm{a}}$ is a doublet with $J_{\mathrm{PC}}=7.6 \mathrm{~Hz}$ ) consistent with the close proximity of the vinylic $\mathrm{CH}$ to the phosphonic acid group. A similar spectroscopic signature was observed for 5 a. Assignments of $\mathrm{H}^{\mathrm{B} 2}, \mathrm{H}^{\mathrm{B} 3}, \mathrm{H}^{\mathrm{A} 3}$ and $\mathrm{H}^{\mathrm{A} 5}$ in $3 \mathbf{a}$ and $5 \mathbf{a}$ (see Schemes 2 and $\mathrm{S} 1 \dagger$ for labels) were made using NOESY crosspeaks as detailed above for compound 2.

Acids $\mathbf{3}$ and $\mathbf{5}$ are poorly soluble in most common organic solvents and show only limited solubility in DMSO; well resolved 1D, HMQC, HMBC and NOESY spectra were obtained for 3 in DMSO- $d_{6}$, but for 5 , only a broadened ${ }^{1} \mathrm{H}$ NMR spectrum could be recorded. Deprotection of 3 a to 3 , and 5 a to 5 was confirmed by the disappearance in the ${ }^{1} \mathrm{H}$ NMR spectra of the signals arising from the ethyl groups in $\mathbf{3 a}$ and $\mathbf{5 a}$; Fig. 1 shows the ${ }^{1} \mathrm{H}$ NMR spectrum of 3 . 


\section{Assembly of dyes on photoanodes}

Photoanodes functionalized with the heteroleptic copper(I) sensitizers $\left[\mathrm{Cu}\left(\mathrm{L}_{\text {anchor }}\right)\left(\mathrm{L}_{\text {ancillary }}\right)\right]^{+}$were assembled in the stepwise protocol (eqn (1)) that we have described in detail elsewhere. ${ }^{8}$ The $\mathrm{FTO} / \mathrm{TiO}_{2}$ surface was sequentially immersed in a DMSO solution of anchoring ligand 1, 2, 3, 4 or 5 (Scheme 1) and then in an acetone solution of $\left[\mathrm{Cu}(6)_{2}\right]\left[\mathrm{PF}_{6}\right]$ or $\left[\mathrm{Cu}(7)_{2}\right]\left[\mathrm{PF}_{6}\right]$. Ancillary ligand 6 (Scheme 3 ) was chosen as a model ligand to allow evaluations with previous studies in which we have compared the performances of different anchoring ligands. ${ }^{29,30}$ Compound 7 (Scheme 3) was selected because we have demonstrated that the introduction of the 6-trifluoromethyl substituent leads to enhanced short-circuit current density $\left(J_{\text {SC }}\right)$ and values of $\eta$ on going from DSCs sensitized by $[\mathrm{Cu}(\mathbf{1})(\mathbf{6})]^{+}$to $[\mathrm{Cu}(\mathbf{1})(7)]^{+} .{ }^{30}$
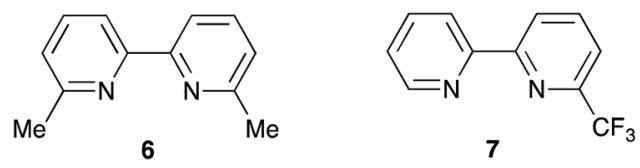

Scheme 3 Structures of ancillary ligands 6 and 7

assuming that the extinction coefficients of the MLCT bands for the four complexes are similar. Fig. 2 also suggests that, for a given anchor, going from phen to bpy $\left([\mathrm{Cu}(\mathbf{4})(7)]^{+}\right.$to $[\mathrm{Cu}(2)(7)]^{+}$, or $[\mathrm{Cu}(5)(7)]^{+}$to $\left.[\mathrm{Cu}(3)(7)]^{+}\right)$leads to better dyeadsorption. This trend is also seen in Fig. $\mathrm{S} 4 \dagger$ which compares the solid-state absorption spectra of transparent FTO/ $\mathrm{TiO}_{2}$ electrodes functionalized with $[\mathrm{Cu}(2)(6)]^{+}$and $[\mathrm{Cu}(4)(6)]^{+}$.

$$
\mathrm{FTO} / \mathrm{TiO}_{2}+\mathrm{L}_{\text {anchor }} \rightarrow \mathrm{FTO} / \mathrm{TiO}_{2} / \mathrm{L}_{\text {anchor }} \frac{\left[\mathrm{Cu}\left(\mathrm{L}_{\text {ancillary }}\right)_{2}\right]^{+}}{-\mathrm{L}_{\text {ancillary }}} \mathrm{FTO} / \mathrm{TiO}_{2} /\left[\left(\mathrm{L}_{\text {anchor }}\right) \mathrm{Cu}\left(\mathrm{L}_{\text {ancillary }}\right)\right]^{+}
$$

Fig. 2 shows the solid-state absorption spectra of commercial FTO/ $/ \mathrm{TiO}_{2}$ electrodes (with no scattering layer) with dyes $[\mathrm{Cu}(2)(7)]^{+},[\mathrm{Cu}(3)(7)]^{+},[\mathrm{Cu}(4)(7)]^{+}$and $[\mathrm{Cu}(5)(7)]^{+}$. Ligands 2 and 4 contain $\mathrm{a} \mathrm{CO}_{2} \mathrm{H}$ anchor, while 3 and 5 have a $\mathrm{PO}_{3} \mathrm{H}_{2}$ anchor; 2 and 3 contain a bpy-metal binding unit, while $\mathbf{4}$ and 5 have a phen-unit. Each functionalized electrode exhibits an absorption maximum around $465 \mathrm{~nm}$ arising from the MLCT band of the copper dye. These values of $\lambda_{\max }$ compare with an MLCT band at $443 \mathrm{~nm}$ in the solution absorption spectrum of $\left[\mathrm{Cu}(7)_{2}\right]$ $\left[\mathrm{PF}_{6}\right]^{30}$ Caution is needed when comparing absolute absorbances in the solid-state spectra; the absorbance with respect to the background tail from the $\mathrm{TiO}_{2}$ is considered. The data in Fig. 2 indicate that the combination of bpy and a $\mathrm{PO}_{3} \mathrm{H}_{2}$ anchor (blue curve in Fig. 2) leads to the best dye-loading; based on solution data for homoleptic complexes we feel justified in
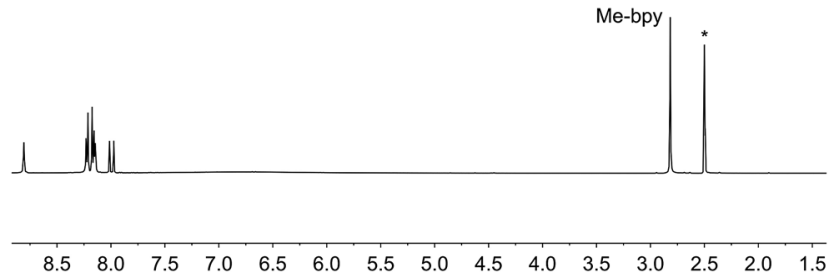

(a)

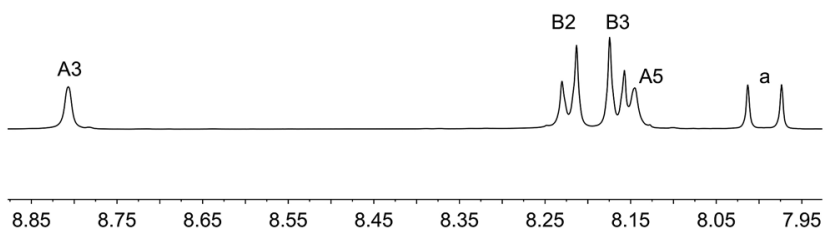

(b)

Fig. 1 (a) The $500 \mathrm{MHz}{ }^{1} \mathrm{H}$ NMR spectrum of a DMSO- $d_{6}$ solution of 3 , and (b) expansion of the non-alkyl region. In the ester 3a signals for the ethyl groups appear at $\delta 4.27$ and 1.44 ppm. * = residual $C_{3} S(O) D_{2} \mathrm{H}$.
Performances of DSCs containing $[\mathrm{Cu}(2)(6)]^{+},[\mathrm{Cu}(3)(6)]^{+}$, $[\mathrm{Cu}(4)(6)]^{+}$and $[\mathrm{Cu}(5)(6)]^{+}$with $\mathrm{I}_{3}{ }^{-} / \mathbf{I}^{-}$electrolyte

Table 1 presents the DSC characteristics of duplicate, masked devices containing the sensitizers $[\mathrm{Cu}(2)(6)]^{+},[\mathrm{Cu}(3)(6)]^{+}$, $[\mathrm{Cu}(4)(6)]^{+}$and $[\mathrm{Cu}(5)(6)]^{+}$, and corresponding $J-V$ curves for the better performing DSC of each pair are shown in Fig. 3; Fig. S5 $\dagger$ gives $J-V$ curves for all the devices. The parameters in Table 1 are compared to those for an N719 reference DSC measured under the same conditions. Results for duplicate cells reveal consistent trends as the anchoring ligand is varied. Both $[\mathrm{Cu}(2)(6)]^{+}$and $[\mathrm{Cu}(3)(6)]^{+}$contain a bpy-metal binding unit in the anchoring ligand, while $[\mathrm{Cu}(\mathbf{4})(\mathbf{6})]^{+}$and $[\mathrm{Cu}(5)(6)]^{+}$contain a phen-coordination domain (Scheme 1). The DSCs sensitized by $[\mathrm{Cu}(2)(6)]^{+}$perform very poorly, exhibiting low $J_{\mathrm{SC}}$, low opencircuit voltage ( $\left.V_{\mathrm{OC}}\right)$, and poor fill-factors (ff). Both $J_{\mathrm{SC}}$ and $V_{\mathrm{OC}}$ are enhanced (Table 1 and Fig. 3) on going from $[\mathrm{Cu}(2)(6)]^{+}$

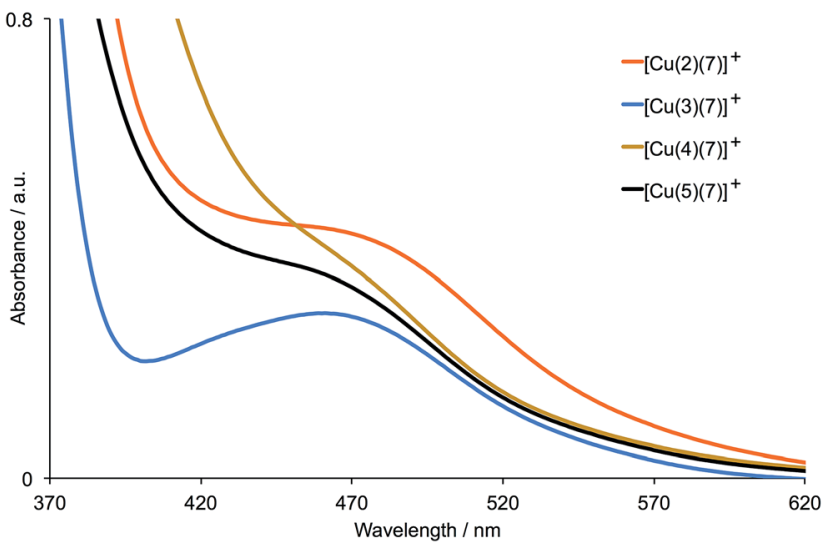

Fig. 2 Solid-state absorption spectra of transparent $\mathrm{FTO} / \mathrm{TiO}_{2}$ electrodes functionalized with $[\mathrm{Cu}(2)(7)]^{+},[\mathrm{Cu}(3)(7)]^{+},[\mathrm{Cu}(4)(7)]^{+}$and $[\mathrm{Cu}(5)(7)]^{+}$. 
Table 1 Parameters of duplicate, masked DSCs with $[\mathrm{Cu}(2)(6)]^{+}$ $[\mathrm{Cu}(3)(6)]^{+},[\mathrm{Cu}(4)(6)]^{+}$and $[\mathrm{Cu}(5)(6)]^{+}$compared to N719; a LOT Quantum Design LS0811 was used as the light source. Measurements were made on the day of DSC fabrication

\begin{tabular}{|c|c|c|c|c|c|}
\hline Dye & $J_{\mathrm{SC}} / \mathrm{mA} \mathrm{cm}^{-2}$ & $V_{\mathrm{OC}} / \mathrm{mV}$ & $\mathrm{ff} / \%$ & $\eta / \%$ & Relative $\eta^{a} / \%$ \\
\hline$[\mathrm{Cu}(2)(6)]^{+}$ & 2.01 & 388 & 49 & 0.38 & 6.4 \\
\hline$[\mathrm{Cu}(2)(6)]^{+}$ & 2.61 & 424 & 54 & 0.60 & 10.1 \\
\hline$[\mathrm{Cu}(3)(6)]^{+}$ & 4.67 & 511 & 73 & 1.75 & 29.4 \\
\hline$[\mathrm{Cu}(3)(6)]^{+}$ & 5.09 & 511 & 73 & 1.91 & 32.0 \\
\hline$[\mathrm{Cu}(4)(6)]^{+}$ & 1.06 & 412 & 71 & 0.31 & 5.2 \\
\hline$[\mathrm{Cu}(\mathbf{4})(\mathbf{6})]^{+}$ & 1.59 & 410 & 72 & 0.47 & 7.9 \\
\hline$[\mathrm{Cu}(\mathbf{5})(\mathbf{6})]^{+}$ & 2.95 & 423 & 72 & 0.90 & 15.1 \\
\hline$[\mathrm{Cu}(5)(6)]^{+}$ & 3.06 & 421 & 72 & 0.93 & 15.6 \\
\hline N719 & 13.75 & 641 & 68 & 5.96 & 100 \\
\hline
\end{tabular}

${ }^{a}$ Relative to N719 set at $100 \%$.

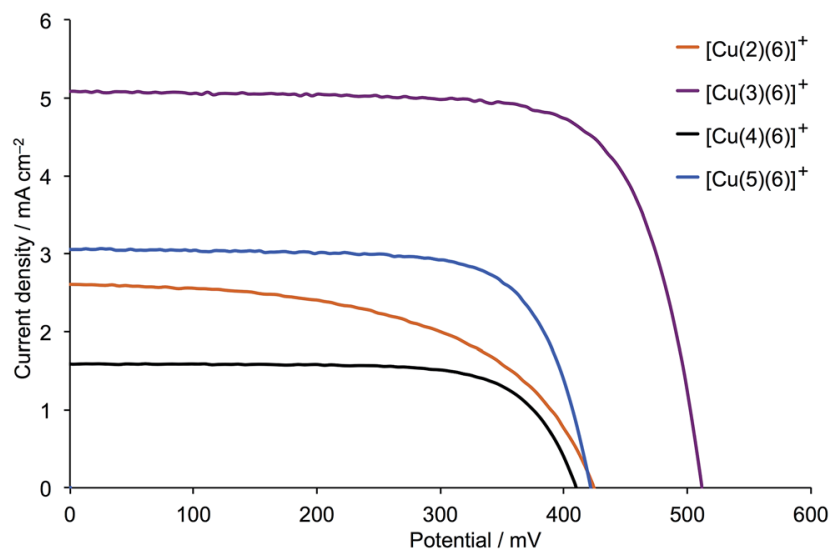

Fig. $3 \mathrm{~J}-V$ curves for DSCs containing $[\mathrm{Cu}(2)(6)]^{+},[\mathrm{Cu}(3)(6)]^{+}$, $[\mathrm{Cu}(4)(6)]^{+}$and $[\mathrm{Cu}(5)(6)]^{+}$combined with $\mathrm{I}_{3}^{-} / \mathrm{I}^{-}$electrolyte. For data for duplicate DSCs, see Fig. S5.†

(cyanoacrylic acid anchor) to $[\mathrm{Cu}(3)(6)]^{+}$((1-cyanovinyl)phosphonic acid anchor). A similar trend is observed on going from DSCs with $[\mathrm{Cu}(\mathbf{4})(\mathbf{6})]^{+}$to $[\mathrm{Cu}(5)(6)]^{+}$, reinforcing the observation that the (1-cyanovinyl)phosphonic acid anchor is superior to cyanoacrylic acid. By far the best performances are observed for DSCs containing $[\mathrm{Cu}(3)(6)]^{+}$; Fig. 3 demonstrates the significant gains in both $J_{\mathrm{SC}}$ and $V_{\mathrm{OC}}$. The fill-factors of $73 \%$ contribute to overall relative efficiencies of $29.4 \%$ and $32.0 \%$ versus $100 \%$ set for the N719 reference DSC. The significantly improved values of $J_{\mathrm{SC}}$ seen for DSCs with $[\mathrm{Cu}(3)(6)]^{+}$compared to cells containing the other three dyes are reflected in the EQE spectra shown in Fig. 4; values of $\mathrm{EQE}_{\max }$ are given in Table 2. All $\mathrm{EQE}_{\max }$ occur at wavelengths of around 480-490 $\mathrm{nm}$ (Table 2), red-shifted from the solid-state absorption maxima $(\sim 465 \mathrm{~nm})$. The performances of the DSCs were also recorded after 7 days, and a comparison of Fig. 3 with Fig. S6 $\uparrow$ shows that the cells are moderately stable; the photoconversion efficiency of the best DSC with dye $[\mathrm{Cu}(3)(6)]^{+}$ decreases from $1.91 \%$ (Table 1) to $1.75 \%$.

The conclusion of this initial investigation is that, for a dye containing the model ancillary ligand $\mathbf{6}$, the preferred anchoring ligand is 3 with a $6,6^{\prime}-\mathrm{Me}_{2}$ bpy metal binding domain

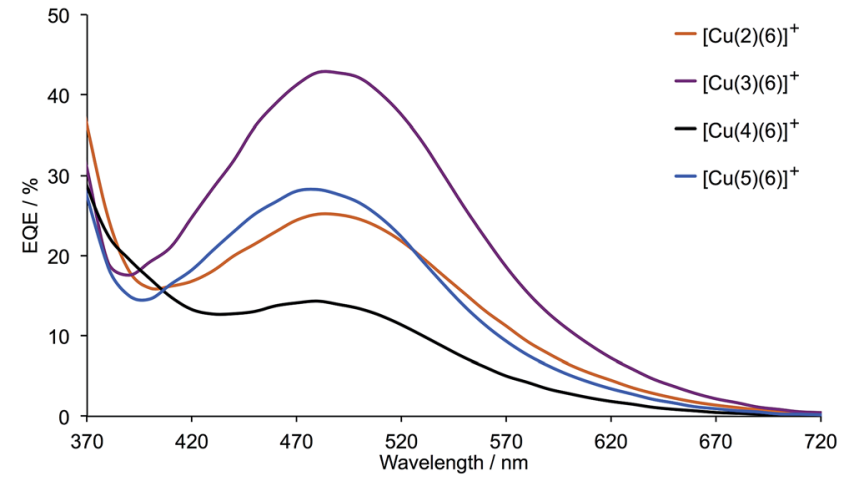

Fig. 4 EQE spectra for DSCs containing dyes $[\mathrm{Cu}(2)(6)]^{+},[\mathrm{Cu}(3)(6)]^{+}$, $[\mathrm{Cu}(4)(6)]^{+}$and $[\mathrm{Cu}(5)(6)]^{+}$combined with $\mathrm{I}_{3}^{-} / \mathrm{I}^{-}$electrolyte. For spectra for duplicate DSCs, see Fig. S7. $\dagger$

Table 2 EQE maxima for duplicate DSCs containing $[\mathrm{Cu}(2)(6)]^{+}$, $[\mathrm{Cu}(3)(6)]^{+},[\mathrm{Cu}(4)(6)]^{+},[\mathrm{Cu}(5)(6)]^{+}[\mathrm{Cu}(3)(7)]^{+}$and combined with $\mathrm{I}_{3}^{-} / \mathrm{I}^{-}$ electrolyte

\begin{tabular}{llllll}
\hline & \multicolumn{1}{l}{ Cell 1 } & & \multicolumn{2}{l}{ Cell 2 } \\
\cline { 2 - 3 } \cline { 5 - 6 } Dye & $\mathrm{EQE}_{\text {max }} / \%$ & $\lambda / \mathrm{nm}$ & & $\mathrm{EQE}_{\max } / \%$ & $\lambda / \mathrm{nm}$ \\
\hline$[\mathrm{Cu}(2)(6)]^{+}$ & 25.1 & 490 & 22.3 & 490 \\
{$[\mathrm{Cu}(3)(6)]^{+}$} & 42.7 & 490 & 40.8 & 490 \\
{$[\mathrm{Cu}(\mathbf{4})(\mathbf{6})]^{+}$} & 14.3 & 480 & 8.3 & 485 \\
{$[\mathrm{Cu}(\mathbf{5})(\mathbf{6})]^{+}$} & 28.2 & 480 & 26.3 & 480 \\
{$[\mathrm{Cu}(3)(7)]^{+}$} & 50.3 & 490 & 48.1 & 490 \\
{$[\mathrm{Cu}(\mathbf{1})(7)]^{+}$} & 53.4 & 480 & 53.0 & 480 \\
\hline
\end{tabular}

functionalized with (1-cyanovinyl)phosphonic acid anchors. The poor performances of dyes with the phen-containing anchors 4 and $\mathbf{5}$ may, in part, be rationalized in terms of the greater flexibility of the bpy ( $v s$. phen) unit. This presumably allows the dyes containing 2 and 3 to adjust more readily to a conformation that facilitates better anchoring to the mesoporous $\mathrm{TiO}_{2}$ surface, as is borne out by the solid-state absorption spectra in Fig. 2. This in turn should lead to enhanced electron injection. It is worth noting that few $\left[\mathrm{Cu}\left(\mathrm{N}^{\wedge} \mathrm{N}\right)_{2}\right]^{+}$ sensitizers reported to date have incorporated phen-based anchors. ${ }^{31-33}$ In two cases, the anchoring carboxylate/ carboxylic acid functionalities are attached to the phen 2,9positions. The few $\left[\mathrm{Cu}\left(\mathrm{N}^{\wedge} \mathrm{N}\right)_{2}\right]^{+}$dyes that exceed $\eta=3 \%$ possess bpy-based anchoring ligands..$^{11,12,34}$

\section{The effect of introducing a $\mathbf{C F}_{3}$ group into the ancillary ligand}

We have previously demonstrated in n-type DSCs that the introduction of $\mathrm{CF}_{3}$ substituents into the 6- or 6,6'-positions of a bpy ancillary ligand leads to a significant improvement in $J_{\mathrm{SC}}$ and a small gain in $V_{\mathrm{OC}}{ }^{30}$ These observations were made using the sensitizers $[\mathrm{Cu}(\mathbf{1})(\mathbf{7})]^{+}$and $[\mathrm{Cu}(\mathbf{1})(\mathbf{8})]^{+}$(see Schemes 1 and 3 for $\mathbf{1}$ and $7 ; \mathbf{8}=6,6^{\prime}$-bis(trifluoromethyl)-2,2'-bipyridine) and by comparing their performances to those of DSCs containing $[\mathrm{Cu}(\mathbf{1})(\mathbf{6})]^{+}, \mathbf{6}$ being the model ligand used above (Scheme 3). Of the two dyes, $[\mathrm{Cu}(\mathbf{1})(7)]^{+}$outperforms $[\mathrm{Cu}(\mathbf{1})(\mathbf{8})]^{+}$. We now 
demonstrate that the introduction of a $\mathrm{CF}_{3}$ group into the ancillary ligand is also beneficial when it is combined with a (1cyanovinyl)phosphonic acid anchor in a copper(I) dye.

Parameters for duplicate DSCs containing the dyes $[\mathrm{Cu}(2)(7)]^{+},[\mathrm{Cu}(3)(7)]^{+},[\mathrm{Cu}(4)(7)]^{+}$and $[\mathrm{Cu}(5)(7)]^{+}$are given in Table 3. $J-V$ curves for the better performing DSC of each pair are shown in Fig. $\mathrm{S} 8 \dagger$ and reveal the same trends with respect to the anchoring ligand as is observed in Fig. 3. This supports the fact that the best values of both $J_{\mathrm{SC}}$ and $V_{\mathrm{OC}}$ are obtained with anchoring ligand 3 (bpy unit combined with phosphonic acid anchor). A comparison of the data in Tables 1 and 3 shows a general increase in both $J_{\mathrm{SC}}$ and $V_{\mathrm{OC}}$ upon introduction of the $\mathrm{CF}_{3}$ group into the ancillary ligand. This is most noteworthy on going from $[\mathrm{Cu}(3)(6)]^{+}$to $[\mathrm{Cu}(3)(7)]^{+}$, with the result that sensitization by $[\mathrm{Cu}(3)(7)]^{+}$leads to photoconversion efficiencies of 2.52 and $2.56 \%$ ( 42.3 and $43.0 \%$ relative to N719 set at 100\%). The increase in the value of $\mathrm{EQE}_{\max }$ (Table 2) on going from $[\mathrm{Cu}(3)(6)]^{+}$to $[\mathrm{Cu}(3)(7)]^{+}$is consistent with the improvement in $J_{\mathrm{SC}}$; EQE spectra are depicted in Fig. $4\left([\mathrm{Cu}(3)(6)]^{+}\right)$and $\mathrm{S}^{\dagger} \dagger$ $\left([\mathrm{Cu}(3)(7)]^{+}\right)$.

\section{Phosphonic acid versus (1-cyanovinyl)phosphonic acid anchor}

As discussed earlier, the phosphonic anchoring ligand $\mathbf{1}$ has been our preferred choice in most recent studies of copper(I)based DSCs. Although replacement of the phenylene spacers in 1 by 2-thienyl units leads to effective anchoring ligands, the improvement in DSC performance is not dramatic. ${ }^{15}$ We now compare the performances of n-type DSCs containing the dyes $[\mathrm{Cu}(\mathbf{3})(7)]^{+}$and $[\mathrm{Cu}(\mathbf{1})(7)]^{+}$in order to assess whether the (1cyanovinyl)phosphonic acid anchor has advantages over a phosphonic acid unit.

DSC parameters for masked cells containing $[\mathrm{Cu}(3)(7)]^{+}$and $[\mathrm{Cu}(\mathbf{1})(7)]^{+}$are given in Table 3 , and $J-V$ curves are plotted in Fig. 5 and S10 $†$. Replacing anchor 1 by 3 leads to a small gain in $J_{\mathrm{SC}}$, the enhanced $J_{\mathrm{SC}}$ of $6.59 \mathrm{~mA} \mathrm{~cm}{ }^{-2}$ approaching half of that achieved by the N719 reference DSC (Table 3). On the other hand, use of 1 leads to a higher $V_{\mathrm{OC}}$, and (with all cells

Table 3 Parameters of duplicate, masked DSCs with $[\mathrm{Cu}(2)(7)]^{+}$, $[\mathrm{Cu}(3)(7)]^{+},[\mathrm{Cu}(4)(7)]^{+},[\mathrm{Cu}(5)(7)]^{+}$and $[\mathrm{Cu}(1)(7)]^{+}$compared to N719; the light source was a LOT Quantum Design LS0811 instrument, and measurements were made on the day of DSC fabrication

\begin{tabular}{lccccc}
\hline Dye & $J_{\mathrm{SC}} / \mathrm{mA} \mathrm{cm}^{-2}$ & $V_{\mathrm{OC}} / \mathrm{mV}$ & $\mathrm{ff} / \%$ & $\eta / \%$ & Relative $\eta^{a} / \%$ \\
\hline$[\mathrm{Cu}(2)(7)]^{+}$ & 2.84 & 447 & 70 & 0.90 & 15.1 \\
{$[\mathrm{Cu}(2)(7)]^{+}$} & 2.17 & 427 & 69 & 0.64 & 10.7 \\
{$[\mathrm{Cu}(3)(7)]^{+}$} & 6.59 & 547 & 71 & 2.56 & 43.0 \\
{$[\mathrm{Cu}(3)(7)]^{+}$} & 6.59 & 548 & 70 & 2.52 & 42.3 \\
{$[\mathrm{Cu}(4)(7)]^{+}$} & 1.89 & 461 & 71 & 0.62 & 10.4 \\
{$[\mathrm{Cu}(4)(7)]^{+}$} & 1.51 & 438 & 70 & 0.46 & 7.7 \\
{$[\mathrm{Cu}(5)(7)]^{+}$} & 3.53 & 445 & 70 & 1.09 & 18.3 \\
{$[\mathrm{Cu}(5)(7)]^{+}$} & 2.30 & 432 & 69 & 0.68 & 11.4 \\
{$[\mathrm{Cu}(\mathbf{1})(7)]^{+}$} & 6.30 & 585 & 68 & 2.51 & 42.1 \\
{$[\mathrm{Cu}(\mathbf{1})(7)]^{+}$} & 6.01 & 576 & 66 & 2.28 & 38.3 \\
$\mathrm{~N} 719$ & 13.75 & 641 & 68 & 5.96 & 100
\end{tabular}

${ }^{a}$ Relative to N719 set at $100 \%$.

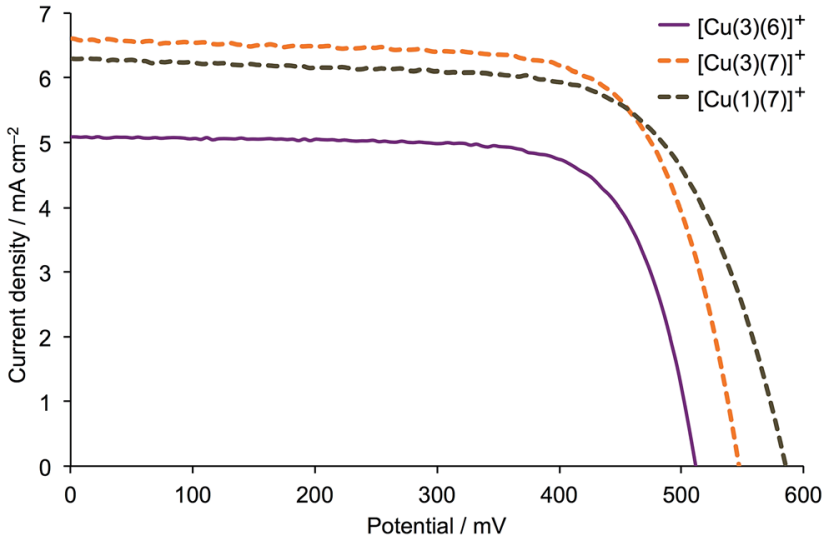

Fig. $5 \mathrm{~J}-V$ curves for DSCs containing $[\mathrm{Cu}(3)(6)]^{+},[\mathrm{Cu}(3)(7)]^{+}$and $[\mathrm{Cu}(1)(7)]^{+}$combined with $\mathrm{I}_{3}^{-} / \mathrm{I}^{-}$electrolyte. For data for duplicate DSCs with $[\mathrm{Cu}(3)(7)]^{+}$and $[\mathrm{Cu}(1)(7)]^{+}$, see Fig. S10.†

exhibiting similar fill-factors of 66-71\%) overall, values of $\eta$ are similar. The EQE spectra in Fig. $\mathrm{S9} \dagger$ show a gain in $\mathrm{EQE}_{\max }$ of $\sim 3$ to $5 \%$ on going from $[\mathrm{Cu}(\mathbf{3})(7)]^{+}$and $[\mathrm{Cu}(\mathbf{1})(7)]^{+}$(Table 3 ) but this is essentially compensated by a red-shift in the spectrum (Fig. S9†).

\section{Electrochemical impedance spectroscopy (EIS): introduction}

To quantify internal charge processes, electrochemical impedance spectroscopy (EIS) was utilized. EIS can be used to investigate physical processes within the DSC, and key parameters such as recombination resistance $\left(R_{\text {rec }}\right)$, chemical capacitance $\left(C_{\mu}\right)$ and transport resistance $\left(R_{\mathrm{t}}\right)$ can be extracted. The measurements are conducted near $V_{\mathrm{OC}}$ where a small AC current of varied frequency is superimposed resulting in an impedance response. The measurements can be carried out under various illumination intensities or in the dark, and are conveniently represented in a Nyquist plot (Fig. 6). In this plot, each semi-circle corresponds to the impedance of a specific interfacial charge transfer process which takes place at a given frequency. If following the real number axis from the origin in a DSC-EIS measurement Nyquist plot, the distance from zero to the first semi-circle is the series resistance $\left(R_{\mathrm{S}}\right)$ predominantly arising from the charge resistance of the $\mathrm{TiO}_{2} / \mathrm{FTO}^{35}$ On going further along the axis, the first circle corresponds to the

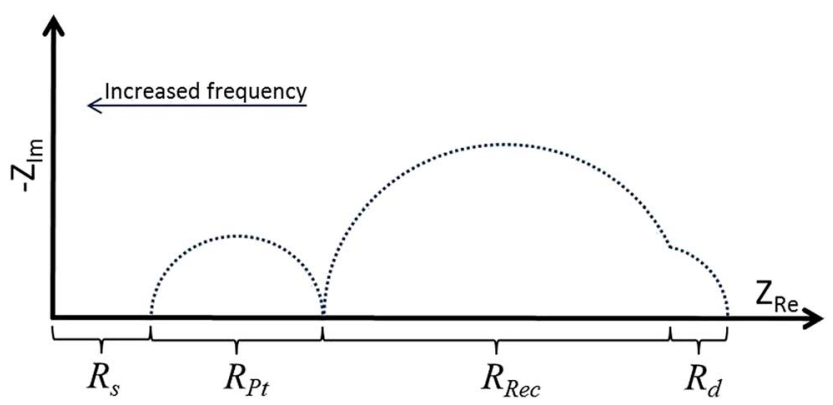

Fig. 6 A schematic illustration of a Nyquist plot of a well functioning DSC at high light intensity. 
cathode/electrolyte charge transfer impedance, and the second is the recombination resistance of the active layer/electrolyte. The small, third semicircle is related to the diffusion resistance of charge carriers in the electrolyte, and may or may not be seen depending on how large it is and on the magnitude of

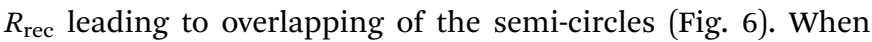
interpreting EIS it is crucial to correctly identify which impedance semi-circle belongs to which process. However, this is easily done for EIS data on DSCs, since a change in bias light intensity should mainly affect only the recombination impedance.

In the following discussion, we first address the factors that contribute to anchoring ligand 3 being superior to 2, 4 and 5 . We follow this with a comparison of the behaviours of DSCs containing anchors $\mathbf{1}$ and $\mathbf{3}$. In all cases, the ancillary ligand in the copper(I) dye is 7 .

\section{EIS for DSCs containing $[\mathrm{Cu}(2)(7)]^{+},[\mathrm{Cu}(3)(7)]^{+},[\mathrm{Cu}(4)(7)]^{+}$ and $[\mathrm{Cu}(5)(7)]^{+}$}

While carboxylic acid anchors are common choices in DSCs, they adsorb less strongly to $\mathrm{TiO}_{2}$ than phosphonic acid anchors, with the latter also showing better long-term stability. ${ }^{36,37}$ However, phosphonic acid anchors show a less efficient charge injection $^{36}$ which should be revealed in EIS measurements as a lower $C_{\mu}$. In Fig. 7a, which shows Nyquist plots for DSCs
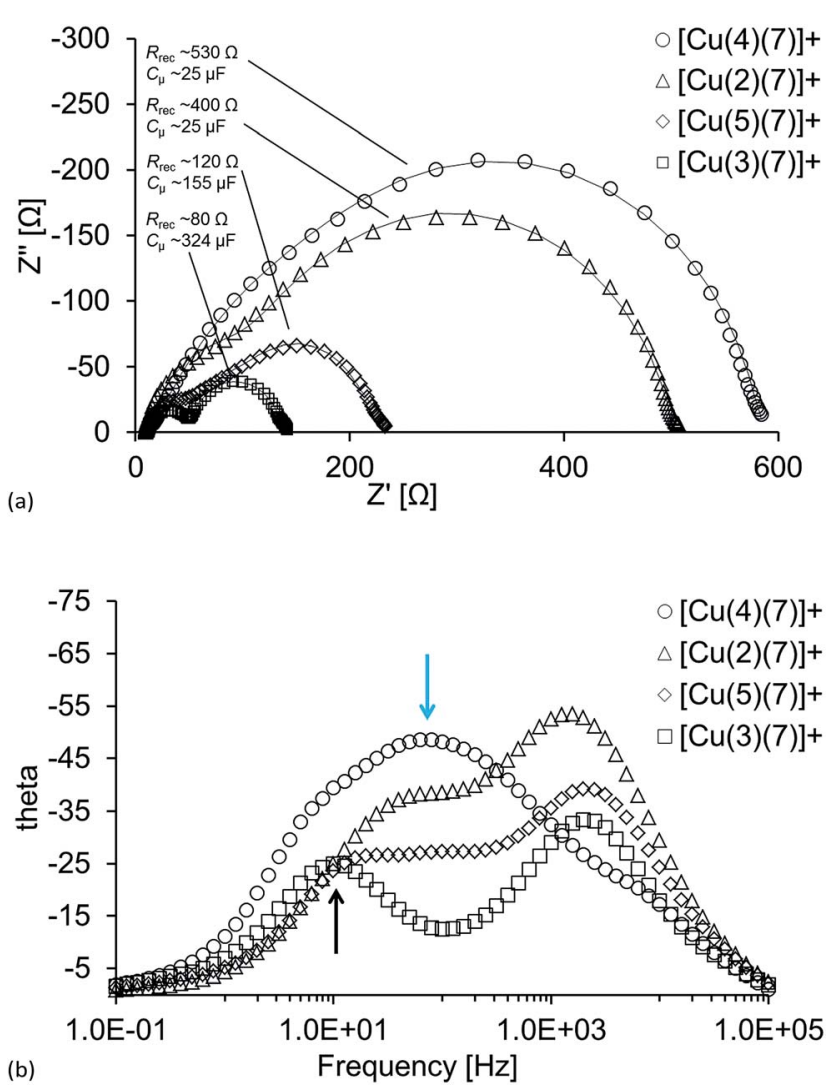

Fig. 7 (a) Nyquist plots and (b) Bode plots for DSCs containing the dyes $[\mathrm{Cu}(2)(7)]^{+},[\mathrm{Cu}(3)(7)]^{+},[\mathrm{Cu}(4)(7)]^{+}$and $[\mathrm{Cu}(5)(7)]^{+}$. See text for interpretation of the blue and black arrows. containing $[\mathrm{Cu}(2)(7)]^{+},[\mathrm{Cu}(3)(7)]^{+},[\mathrm{Cu}(4)(7)]^{+}$and $[\mathrm{Cu}(5)(7)]^{+}$, it can, however, be seen that this is not the case. The carboxylic acid anchors exhibit a much lower chemical capacitance than their phosphonic acid counterparts. At the same time, the recombination resistances for these samples are much larger than for dyes with the phosphonic acid anchors. This suggests that the electron injection through the carboxylic acid anchors is poor and therefore the resulting charge in the semiconductor is low. A low density of injected electrons means, aside from low $C_{\mu}$, that few electrons are able to undergo electron back reactions, which is shown in the EIS as high $R_{\text {rec}}$. The reason why the charge transfer of the DSCs with $[\mathrm{Cu}(2)(7)]^{+}$and $[\mathrm{Cu}(4)(7)]^{+}$is so poor, results from disruption of electron transport due to reduced dye adhesion and most likely not because these dyes themselves are better at suppressing recombination reactions of injected electrons. The more flexible structure in the bpy unit together with the stronger adhesion given by the phosphonic acid anchor result in the best performing anchor and a much higher chemical capacitance which is consequently seen in the DSC with $[\mathrm{Cu}(3)(7)]^{+}$. Additionally, the low $J_{\mathrm{SC}}$ (Table 3 ) supports that the electron transport is disturbed, especially for $[\mathrm{Cu}(2)(7)]^{+}$ and $[\mathrm{Cu}(4)(7)]^{+}$.

The indistinct separation between the first and second semicircles for DSCs with $[\mathrm{Cu}(2)(7)]^{+},[\mathrm{Cu}(\mathbf{4})(7)]^{+}$and $[\mathrm{Cu}(5)(7)]^{+}$ (Fig. 7a) indicate that the transport resistance $\left(R_{\mathrm{t}}\right)$ is very high (especially for $[\mathrm{Cu}(4)(7)]^{+}$where $R_{\mathrm{t}}>R_{\mathrm{rec}}$ ), even at high light intensities. It can also be seen in the Bode plot (Fig. 7b) that the better the performance of the DSC (Table 3), the more distinct is the phase shift for the $\mathrm{TiO}_{2} /$ dye/electrolyte interface (black arrow), which means that the $\mathrm{TiO}_{2}$ has a higher $C_{\mu}$ of the conduction band, i.e. more electrons populate it. The poorly defined separation of the semi-circles in the Nyquist plot in Fig. 7a for the DSC with $[\mathrm{Cu}(4)(7)]^{+}$due to the exceptionally high $R_{\mathrm{t}}$ is also illustrated in the Bode plot and highlighted by the blue arrow.

As mentioned earlier, isomerization of the $\mathrm{C}=\mathrm{C}$ double bond in cyanoacrylic acid anchors has been shown to occur upon irradiation. ${ }^{25}$ This could be the reason why the DSCs containing dyes with anchors 2-5 show such dramatic performance differences. Firstly, the anchor would benefit from a more flexible structure (i.e. bpy rather than phen-based) with the ability to adapt to photoisomerization. Secondly, the anchor would benefit from a stronger binding group (phosphonic rather carboxylic acid) with a larger ability to compensate for conformational changes.

\section{EIS for DSCs containing $[\mathrm{Cu}(1)(7)]^{+}$and $[\mathrm{Cu}(3)(7)]^{+}$}

Fig. 8 shows the Nyquist plots for DSCs containing $[\mathrm{Cu}(\mathbf{1})(7)]^{+}$ and $[\mathrm{Cu}(3)(7)]^{+}$where $R_{\mathrm{Pt}}$ is as good as unaffected while $R_{\text {rec }}$ varies drastically depending on the given light intensity. The results obtained at high light intensities are also presented in Table 4 and in Fig. 9 where the chemical capacitance is depicted.

As discussed earlier, $C_{\mu}$ values for $[\mathrm{Cu}(3)(7)]^{+}$indicate that ligand 3 anchors well to the surface, and the DSC efficiencies are comparable to those of DSCs containing $[\mathrm{Cu}(\mathbf{1})(7)]^{+}$. However, it can be seen in Fig. 8 that the recombination resistance is larger for $[\mathrm{Cu}(\mathbf{1})(\mathbf{7})]^{+}$at all light intensities which indicates a more 

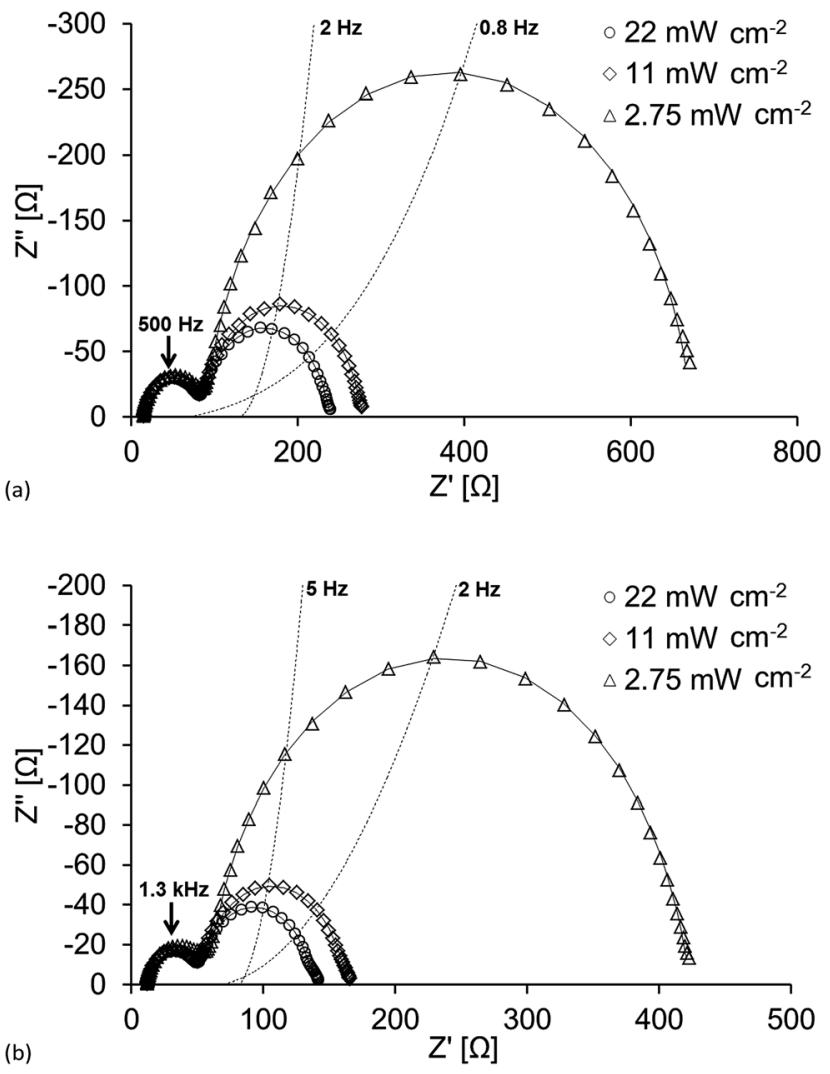

Fig. 8 Nyquist plot of DSCs with the dyes (a) $[\mathrm{Cu}(1)(7)]^{+}$and (b) $[\mathrm{Cu}(3)(7)]^{+}$under different light intensities.

Table 4 Impedance data obtained during measurements at $22 \mathrm{~mW}$ $\mathrm{cm}^{-2}$

\begin{tabular}{lrrrrrrr}
\hline Dye & $R_{\mathrm{t}}$ & $R_{\mathrm{rec}}$ & $C_{\mu}$ & $R_{\mathrm{Pt}}$ & $C_{\mathrm{Pt}}$ & $\tau$ & $L_{\mathrm{d}} / L$ \\
\hline$[\mathrm{Cu}(\mathbf{1})(7)]^{+}$cell 1 & 57 & 151 & 460 & 52 & 5 & 70 & 1.6 \\
{$[\mathrm{Cu}(\mathbf{1})(7)]^{+}$cell 2 } & 62 & 156 & 388 & 52 & 4 & 60 & 1.6 \\
{$[\mathrm{Cu}(3)(7)]^{+}$cell 1 } & 36 & 83 & 325 & 28 & 5 & 27 & 1.5 \\
{$[\mathrm{Cu}(3)(7)]^{+}$cell 2 } & 51 & 86 & 346 & 42 & 5 & 30 & 1.3
\end{tabular}

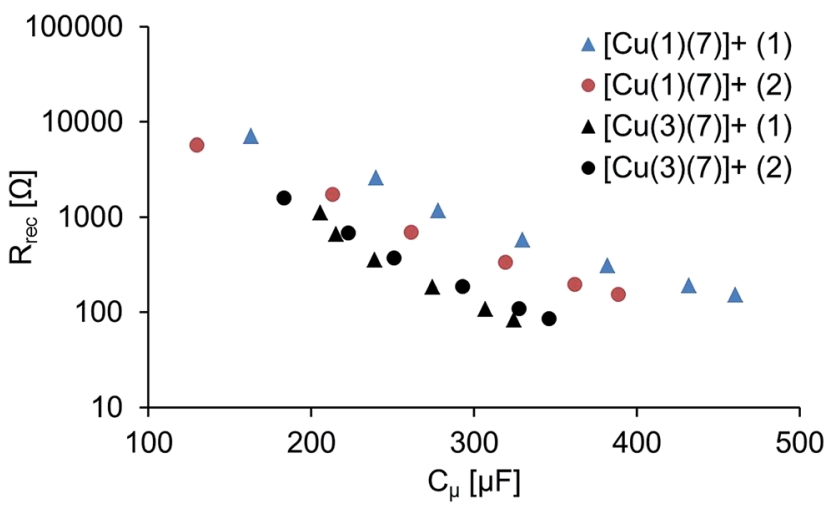

Fig. $9 R_{\text {rec }}$ vs. $C_{\mu}$ of the duplicate DSCs with dyes $[\mathrm{Cu}(1)(7)]^{+}$and $[\mathrm{Cu}(3)(7)]^{+}$. The numbers (1) and (2) refer to the duplicate cells. efficient charge injection which also yields higher $V_{\mathrm{OC}}$ (Table 3). Again, the photoisomerization ${ }^{25}$ of $[\mathrm{Cu}(3)(7)]^{+}$may explain these differences, reducing the charge injection. Additionally, if the physical geometry of the dye changes, the accessibility of the electrolyte to the $\mathrm{TiO}_{2}$ may also be affected. This could play a role in the amount of oxidized electrolyte residing close to the surface. This in turn will expedite electron recombination with the electrolyte leading to a decrease in $R_{\text {rec }}$, and in addition, the conduction band level will decrease and $R_{\mathrm{t}}$ will change as a consequence of charge compensation. This is dealt with in detail later when we discuss $R_{\mathrm{t}}$. Finally, another contributing factor might be that the electronegative cyano-acceptor group in $[\mathrm{Cu}(3)(7)]^{+}$not only has an advantageous impact on the internal charge transport within the dye, (i.e. directing electrons towards the semi-conductor), but also facilitates unwanted backreactions of charge already transferred to the semi-conductor.

The measured chemical capacitance, $C_{\mu}$, is related to the total density of electrons in the $\mathrm{TiO}_{2} \cdot{ }^{38}$ As the light intensity (LI) increases and reaches $\mathrm{LI}_{\max }$, the band gap is smaller and the measured capacitance will ultimately stem from electrons residing in the conduction band of the $\mathrm{TiO}_{2}$. Fig. 9 further highlights the relationship between $R_{\text {rec }}$ and $C_{\mu}$; as the light intensity increases, $R_{\text {rec }}$ of the DSCs containing $[\mathrm{Cu}(3)(7)]$ also decreases more rapid than the other while the capacitance increases at a lower degree.

The electron lifetime, $\tau$, (Table 4 ) is calculated as the product of $R_{\text {rec }} C_{\mu}$ and is significantly higher for $[\mathrm{Cu}(\mathbf{1})(7)]^{+} . \tau$ is the lifetime of injected electrons and a higher $\tau$ implies a more efficient charge collection. As mentioned above, $R_{\mathrm{t}}$ is the resistance to electron transport in the $\mathrm{TiO}_{2}$. A larger $R_{\mathrm{t}}$ means that the transit time for the electron is larger. If the transit time is larger than the electron lifetime of injected electrons the charge collection will be ineffective. The length of diffusion, $L_{\mathrm{d}}$, describes the length of the diffusion pathway in the semiconductor for electrons to back react and should be as long as possible, but at least as long as the $\mathrm{TiO}_{2}$ layer thickness $(L) \cdot{ }^{39} \mathrm{In}$ other words $L_{\mathrm{d}} / L$ (which can be calculated as $\sqrt{R_{\text {rec }} / R_{\mathrm{t}}}$ ) should be larger than 1 . This is the case for all DSCs and slightly larger for that with $[\mathrm{Cu}(\mathbf{1})(7)]^{+}$due to the higher $R_{\text {rec }}$.

$R_{\mathrm{t}}$ can be seen as a $45^{\circ}$ slope between the cathode semi-circle and the recombination one, preferentially at lower bias voltage

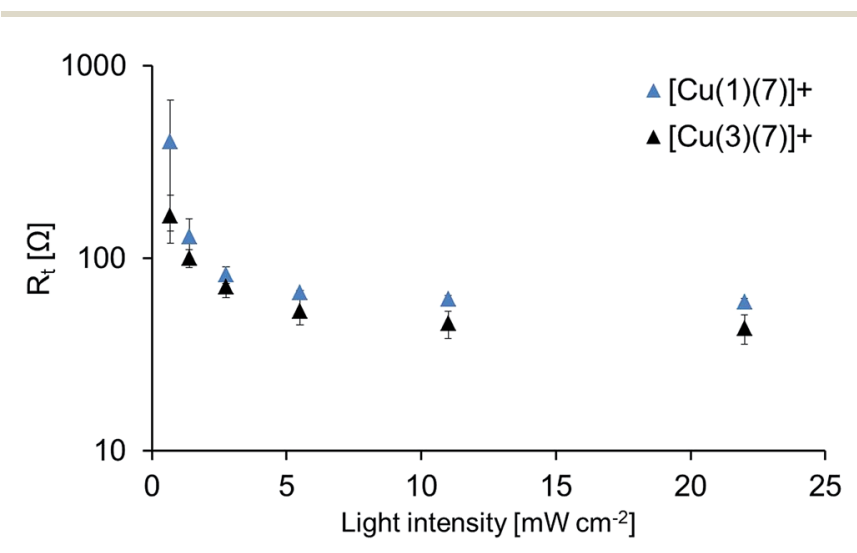

Fig. $10 R_{\mathrm{t}}$ of the duplicate DSCs with dyes $[\mathrm{Cu}(1)(7)]^{+}$and $[\mathrm{Cu}(3)(7)]^{+}$. 
potentials in well-functioning DSCs. Fig. 10 shows $R_{\mathrm{t}}$ values for DSCs with dyes $[\mathrm{Cu}(\mathbf{1})(7)]^{+}$and $[\mathrm{Cu}(3)(7)]^{+}$where the higher $R_{\mathrm{t}}$ is for $[\mathrm{Cu}(\mathbf{1})(7)]^{+}$. As mentioned earlier, changes in $R_{\mathrm{t}}$ generally occur if the electrolyte composition is altered, ${ }^{38}$ which in turn is an effect of the conduction band (CB) level. The CB level changes with the ability of electrolyte constituents to charge compensate the electrons in the CB. ${ }^{40}$ More extensive charge compensation lowers the CB level, resulting in lower $V_{\mathrm{OC}}$ and $R_{\mathrm{t}}$ but higher $J_{\mathrm{SC}}$. The lower $R_{\mathrm{t}}$ for the cell with $[\mathrm{Cu}(3)(7)]^{+}$is indeed accompanied by a higher $J_{\mathrm{SC}}$ and lower $V_{\mathrm{OC}}$. Yet, in this study the electrolyte composition is the same in all DSCs and the only difference is the dye. A reasonable explanation is that photoisomerization ${ }^{25}$ of the anchoring ligand upon dye irradiation leads to difference in accessibility of the $\mathrm{TiO}_{2}$ surface towards the electrolyte. This would result in a changed charge compensation situation, which, in turn, has an impact on the CB and therefor on $R_{\mathrm{t}}$.

\section{Conclusions}

The preparation and characterization of the anchoring ligands 2-5 for $\left[\mathrm{Cu}\left(\mathrm{L}_{\text {anchor }}\right)\left(\mathrm{L}_{\text {ancillary }}\right)\right]^{+}$sensitizers have been described. Ligands 2 and 3 contain a bpy coordination site, while $\mathbf{4}$ and $\mathbf{5}$ contain a phen unit; 2 and 4 contain cyanoacrylic acid anchoring units, and $\mathbf{3}$ and $\mathbf{5}$ possess (1-cyanovinyl)phosphonic acid anchors. The performances of DSCs containing $\left[\mathrm{Cu}\left(\mathrm{L}_{\text {anchor }}\right)\left(\mathrm{L}_{\text {ancillary }}\right)\right]^{+}$dyes with $\mathrm{L}_{\text {anchor }}=2,3,4$ or 5 and $\mathrm{L}_{\text {ancillary }}=6$ or 7 reveal that, for both ancillary ligands, anchor 3 is the most beneficial, leading to higher values of both $J_{\mathrm{SC}}$ and $V_{\mathrm{OC}}$. Values of $\eta=2.56$ and $2.52 \%$ (relative to $5.96 \%$ for N719) for DSCs with the dye $[\mathrm{Cu}(3)(7)]^{+}$compare with 1.91 and $1.71 \%$ for $[\mathrm{Cu}(3)(6)]^{+}$, reaffirming ${ }^{30}$ the favourable effects of introducing a 6-trifluoromethyl substituent into the ancillary ligand. We propose that the better performances of dyes containing 2 and $\mathbf{3}$ compared to those with $\mathbf{4}$ and $\mathbf{5}$ arise from the greater flexibility of the bpy $v s$. phen unit, allowing dyes containing 2 and 3 to adopt a conformation that gives better surface coverage on mesoporous $\mathrm{TiO}_{2}$. An EIS investigation of DSCs containing dyes $[\mathrm{Cu}(2)(7)]^{+},[\mathrm{Cu}(3)(7)]^{+},[\mathrm{Cu}(4)(7)]^{+}$and $[\mathrm{Cu}(5)(7)]^{+}$supports the fact that the main limiting factor for DSCs except that with $[\mathrm{Cu}(3)(7)]^{+}$is poor dye adhesion. The contributing factors (poorer carboxylic acid adhesion compared to phosphonic acid, the more rigid structure of phen versus bpy, and possible photoisomerization of the alkene unit) render $[\mathrm{Cu}(4)(7)]^{+}$the poorest dye. This is manifested in the EIS measurements as high recombination resistance together with very low chemical capacitance.

In previous investigations, phosphonic acid $\mathbf{1}$ has been our favoured anchoring ligand in bis(diimine)copper(I) dyes. Replacing 1 by 3 leads to a small gain in $J_{\mathrm{SC}}$, but dyes with anchor 1 have enhanced $V_{\mathrm{OC}}$ compared to those with $\mathbf{3}$. The EIS data for DSCs with dyes containing anchors $\mathbf{3}$ or $\mathbf{1}$ are compared, and the latter has a higher recombination resistance and chemical capacitance although the former presents a lower transport resistance. EIS measurements confirm that $[\mathrm{Cu}(\mathbf{1})(7)]^{+}$ has a higher $R_{\text {rec }}$ than $[\mathrm{Cu}(3)(7)]^{+}$, in agreement with the higher $V_{\mathrm{OC}}$ for $[\mathrm{Cu}(\mathbf{1})(7)]^{+}$. The lower $R_{\text {rec }}$ observed for $[\mathrm{Cu}(3)(7)]^{+}$is due to a more inefficient charge injection, and we propose that this may arise from photo-isomerization, reducing the charge injection, and the vicinity of the HOMO orbital to the surface, which could promote back reactions. Furthermore, $R_{\mathrm{t}}$ is lower for $[\mathrm{Cu}(3)(7)]^{+}$, which is a consequence of a lower conduction band level. This indicates that charge compensation for injected electrons occurs more effectively, which is also manifested in the higher $J_{\mathrm{SC}}$ for $[\mathrm{Cu}(3)(7)]^{+}$. The reason for this currently remains unclear.

\section{Acknowledgements}

We acknowledge the Swiss National Science Foundation (Grant number 200020_144500), the Swiss Nano Institute (for the purchase of the EIS instrument) and the University of Basel for financial support. Fabian Brunner (University of Basel) is thanked for synthesizing ligand 7.

\section{Notes and references}

1 B. O'Regan and M. Grätzel, Nature, 1991, 353, 737; M. Grätzel, Acc. Chem. Res., 2009, 42, 1788; M. Grätzel, Inorg. Chem., 2005, 44, 6841; M. Grätzel, J. Photochem. Photobiol., C, 2003, 4, 145 and references therein.

2 Dye Sensitized Solar Cells, ed. K. Kalyanasundaram, CRC Press, Boca Raton, 2010.

3 A. Hagfeldt, G. Boschloo, L. Sun, L. Kloo and H. Pettersson, Chem. Rev., 2010, 110, 6595.

4 L. Zhang and J. M. Cole, ACS Appl. Mater. Interfaces, 2015, 7, 3427.

5 T. Higashino and H. Imahori, Dalton Trans., 2015, 44, 448.

6 A. Mishra, M. K. R. Fischer and P. Bäuerle, Angew. Chem., Int. Ed., 2009, 48, 2474.

7 F. Ambrosio, N. Martsinovich and A. Troisi, J. Phys. Chem. Lett., 2012, 3, 1531.

8 E. Schönhofer, B. Bozic-Weber, C. J. Martin, E. C. Constable, C. E. Housecroft and J. A. Zampese, Dyes Pigm., 2015, 115, 154.

9 C. E. Housecroft and E. C. Constable, Chem. Soc. Rev., 2015, 44, 8386.

10 M. Sandroni, M. Kayanuma, A. Planchat, N. Szuwarski, E. Blart, Y. Pellegrin, C. Daniel, M. Boujtita and F. Odobel, Dalton Trans., 2013, 42, 10818 and references therein.

11 F. J. Malzner, S. Y. Brauchli, E. C. Constable, C. E. Housecroft and M. Neuburger, RSC Adv., 2014, 4, 48712.

12 M. Sandroni, L. Favereau, A. Planchat, H. Akdas-Kilig, N. Szuwarski, Y. Pellegrin, E. Blart, H. Le Bozec, M. Boujtita and F. Odobel, J. Mater. Chem. A, 2014, 2, 9944.

13 B. Bozic-Weber, E. C. Constable, C. E. Housecroft, P. Kopecky, M. Neuburger and J. A. Zampese, Dalton Trans., 2011, 40, 12584.

14 B. Bozic-Weber, S. Y. Brauchli, E. C. Constable, S. O. Fürer, C. E. Housecroft, F. J. Malzner, I. A. Wright and J. A. Zampese, Dalton Trans., 2013, 42, 12293.

15 Y. M. Klein, M. Willgert, A. Prescimone, E. C. Constable and C. E. Housecroft, Dalton Trans., 2016, 45, 4659. 
16 K. A. Wills, H. A. Mandujano-Ramírez, G. Merino, G. Oskam, P. Cowper, M. D. Jones, P. J. Cameron and S. E. Lewis, Dyes Pigm., 2016, 134, 419.

17 N. Armaroli, G. Accorsi, F. Cardinali and A. Listorti, Top. Curr. Chem., 2007, 280, 69.

18 B. Bozic-Weber, S. Y. Brauchli, E. C. Constable, S. O. Fürer, C. E. Housecroft, F. J. Malzner, I. A. Wright and J. A. Zampese, Dalton Trans., 2013, 42, 12293.

19 D. O. Kirsanov, N. E. Borisova, M. D. Reshetova, A. V. Ivanov, L. A. Korotkov, I. I. Eliseev, M. Yu. Alyapyshev, I. G. Spiridonov, A. V. Legin, Yu. G. Vlasov and V. A. Babain, Russ. Chem. Bull., 2012, 61, 881.

20 A. F. Larsen and T. Ulven, Org. Lett., 2011, 13, 3546.

21 B. Bozic-Weber, V. Chaurin, E. C. Constable, C. E. Housecroft, M. Meuwly, M. Neuburger, J. A. Rudd, E. Schönhofer and L. Siegfried, Dalton Trans., 2012, 41, 14157.

22 Y.-J. Yuan, Z.-T. Yu, J.-Y. Zhang and Z.-G. Zou, Dalton Trans., 2012, 41, 9594.

23 H. J. Snaith, Energy Environ. Sci., 2012, 5, 6513.

24 H. J. Snaith, Nat. Photonics, 2012, 6, 337.

25 B. Zietz, E. Gabrielsson, V. Johansson, A. M. El-Zohry, L. Sun and L. Kloo, Phys. Chem. Chem. Phys., 2014, 16, 2251.

26 F. H. Allen, Acta Crystallogr., Sect. B: Struct. Sci., 2002, 58, 380.

27 C. R. Groom, I. J. Bruno, M. P. Lightfoot and S. C. Ward, Acta Crystallogr., Sect. B: Struct. Sci., 2016, 72, 171.

28 I. J. Bruno, J. C. Cole, P. R. Edgington, M. Kessler, C. F. Macrae, P. McCabe, J. Pearson and R. Taylor, Acta Crystallogr., Sect. B: Struct. Sci., 2002, 58, 389.
29 F. J. Malzner, S. Y. Brauchli, E. Schönhofer, E. C. Constable and C. E. Housecroft, Polyhedron, 2014, 82, 116.

30 F. Brunner, M. Klein, S. Keller, C. D. Morris, A. Prescimone, E. C. Constable and C. E. Housecroft, RSC Adv., 2015, 5, 58694.

31 L. N. Ashbrook and C. M. Elliott, J. Phys. Chem. C, 2013, 117, 3853.

32 N. Alonso-Vante, J.-F. Nierengarten and J.-P. Sauvage, J. Chem. Soc., Dalton Trans., 1994, 1649.

33 M. W. Mara, D. N. Bowman, O. Buyukcakir, M. L. Shelby, K. Haldrup, J. Huang, M. R. Harpham, A. B. Stickrath, X. Zhang, J. F. Stoddart, A. Coskun, E. Jakubikova and L. X. Chen, J. Am. Chem. Soc., 2015, 137, 9670.

34 S. O. Fürer, B. Bozic-Weber, T. Schefer, C. Wobill, E. C. Constable, C. E. Housecroft and M. Willgert, J. Mater. Chem. A, 2016, 4, 12995.

35 Q. Wang, J.-E. Moser and M. Grätzel, J. Phys. Chem. B, 2005, 109, 14945.

36 A. Abate, R. Perez-Tejada, K. Wojciechowski, J. M. Foster, A. Sadhanala, U. Steiner, H. J. Snaith, S. Franco and J. Orduna, Phys. Chem. Chem. Phys., 2015, 17, 18780.

37 B. J. Brennan, P. M. J. Llansola, P. A. Liddell, T. A. Moore, A. L. Moore and D. Gust, Phys. Chem. Chem. Phys., 2013, 15, 16605.

38 F. Fabregat-Santiago, J. Bisquert, G. Garcia-Belmonte, G. Boschloo and A. Hagfeldt, Sol. Energy Mater. Sol. Cells, 2005, 87, 117.

39 J. Bisquert, F. Fabregat-Santiago, I. Mora-Sero, G. GarciaBelmonte and S. Gimenez, J. Phys. Chem. C, 2009, 113, 17278. 40 Y. Liu, A. Hagfeldt, X.-R. Xiao and S.-E. Lindquist, Sol. Energy Mater. Sol. Cells, 1998, 55, 267. 